\title{
Israel: Technical Note on Stress Test of the Banking, Insurance and Pension Sectors
}

This paper was prepared based on the information available at the time it was completed in March 2012. The views expressed in this document are those of the staff team and do not necessarily reflect the views of the government of Israel or the Executive Board of the IMF.

The policy of publication of staff reports and other documents by the IMF allows for the deletion of market-sensitive information.

Copies of this report are available to the public from

International Monetary Fund $\bullet$ Publication Services

700 19th Street, N.W. • Washington, D.C. 20431

Telephone: (202) 623-7430 • Telefax: (202) 623-7201

E-mail: publications@imf.org • Internet: http://www.imf.org

\section{International Monetary Fund Washington, D.C.}


FinANCIAL SECTOR ASSESSMENT PROGRAM UPDATE

\section{ISRAEL}

StRess Test of the BANKING, InsuRANCE AND PENSION SECTORS

\section{TECHNICAL NOTE}

MARCH 2012 
Glossary .4

Executive Summary. .5

I. Background on Banking, Insurance, Household, Corporate Sector Structure and Risks.......8

II. Macroeconomic Scenarios for Bank Stress Testing 12

III. Top-Down Balance Sheet Solvency Stress Tests for Banks.......................................15

A. Stress Testing by the BSD .................................................................... 15

B. Assumptions for the FSAP Update Bank Balance Sheet Stress Tests ...................15

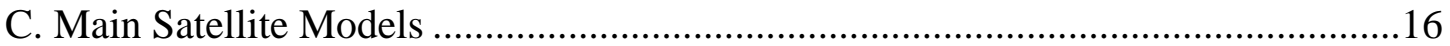

D. Other Elements of Balance Sheet Stress Tests..................................................17

E. Results of Balance Sheet Stress Tests .............................................................. 17

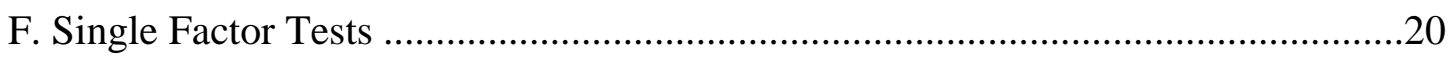

IV. Top-Down Contingent Claims Analysis Stress Tests for Banks ..................................20

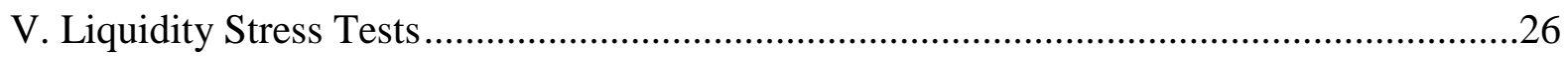

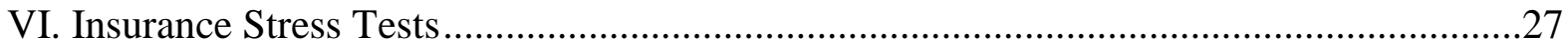

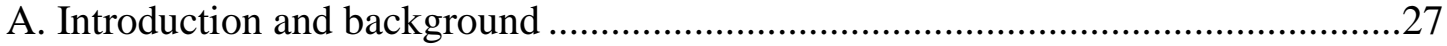

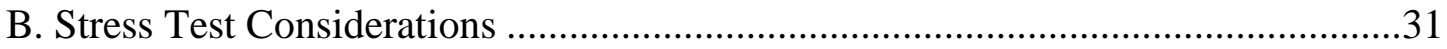

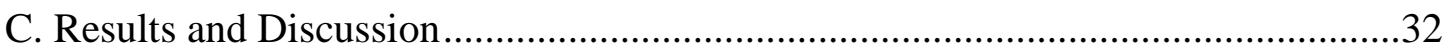

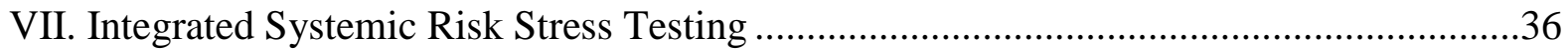

Tables

1. Stress Testing Scenario Parameters ....................................................................... 14

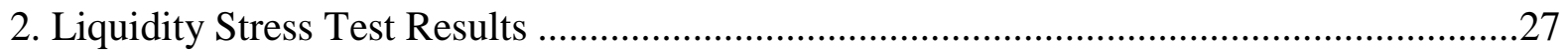

Figures

1. Banks and Insurance Companies ................................................................................. 10

2. Household and Corporate Sector Indicators ................................................................ 11

3. Bank Balance Sheet Stress Test Results .......................................................................19

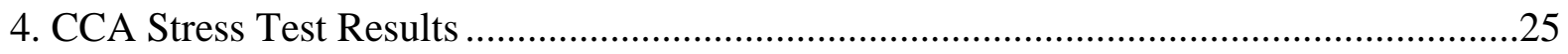

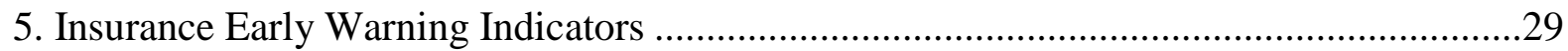

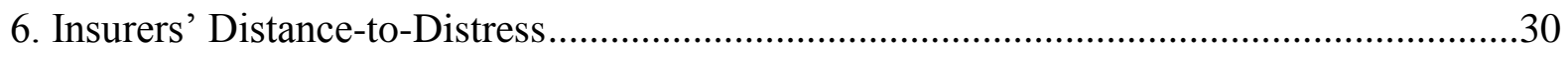

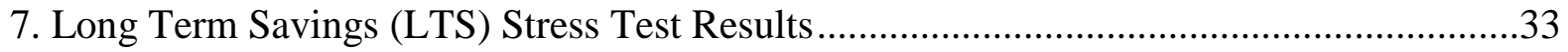

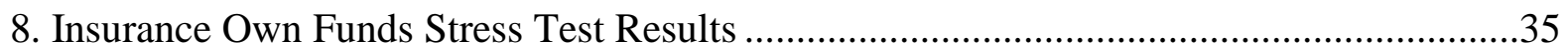


Box

1 MKMV CCA Model Calibration and Calculation of EDFs and Fair Value Spreads

Appendices

I. Stress Test Matrix for Banking: Solvency Risk

II. Satellite Models and Assumptions for Balance Sheet Stress Testing ...............................39

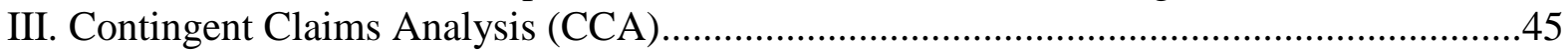

IV. Econometric Model Linking Macro Factors to CCA Model ..........................................51

V. Insurance Test Matrix for Long Term Savings Providers.............................................55

Appendix Table

3. Regression Results for Banks

Appendix Figures

9. Housing Credit LLP to Credit....................................................................................40

10 Quarterly Changes in the Composite Index and GDP ...............................................42

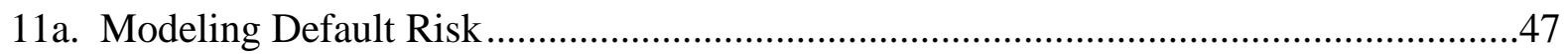

11b. Actual vs. Risk Neutral Default Probabilities ...........................................................48

12. Historical Market Sharpe Ratio and Projected for Adverse Scenario 2 ...........................50

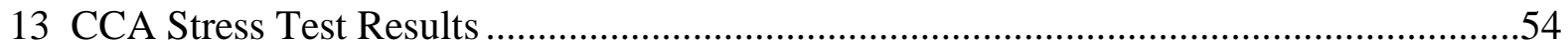

Appendix Box

2. Market Price of Risk

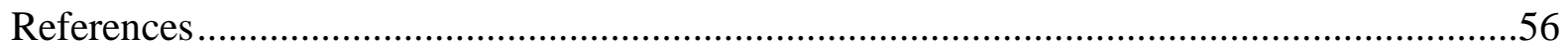




\section{GLOSSARY}

$\begin{array}{ll}\text { BOI } & \text { Bank of Israel } \\ \text { BSD } & \text { Banking Supervision Department } \\ \text { BSM } & \text { Black-Scholes-Merton } \\ \text { CCA } & \text { Contingent Claims Analysis } \\ \text { CMISD } & \text { Capital Markets, Insurance and Savings Division } \\ \text { CT1 } & \text { Core Tier 1 Capital } \\ \text { D2D } & \text { Distance to distress } \\ \text { EAD } & \text { Exposure at default } \\ \text { EL } & \text { Expected loss } \\ \text { EDF } & \text { Expected default frequency } \\ \text { ES } & \text { Expected shortfall } \\ \text { EVT } & \text { Extreme value theory } \\ \text { FSAP } & \text { Financial Sector Assessment Program } \\ \text { GEV } & \text { Generalized extreme value } \\ \text { LGD } & \text { Loss given default } \\ \text { LLP } & \text { Loan Loss Provisions } \\ \text { LTS } & \text { Long-term Savings } \\ \text { LTV } & \text { Loan to Value } \\ \text { M KMV } & \text { Moody's KMV } \\ \text { MOF } & \text { Ministry of Finance } \\ \text { MPR } & \text { Market price of risk } \\ \text { NIS } & \text { New Israeli Shekel } \\ \text { PD } & \text { Probability of default } \\ \text { RWA } & \text { Risk-weighted assets } \\ \text { RD } & \text { Research Department of BOI } \\ \text { RNDP } & \text { Risk neutral default probability } \\ \text { SR } & \text { Sharpe ratio } \\ \text { ST } & \text { Stress Test } \\ \text { T1 } & \text { Tier 1 capital } \\ \text { VaR } & \text { Value-at-risk } \\ \text { VAR } & \text { Vector autoregression } \\ & \end{array}$




\section{EXECUTIVE SUMMARY}

The Israel Financial Sector Assessment Program (FSAP) Update stress testing exercise comprises a comprehensive analysis of solvency and liquidity risks of key banking and insurance institutions. Stress tests were carried out in collaboration with the authorities. The FSAP Update team would like to express its appreciation for the contributions of the staff of the BOI and the Capital Markets, Insurance and Savings Division (CMISD) of the Ministry of Finance (MOF) in the undertaking of this exercise. The Israeli staff involved were consistently open, knowledgeable and innovative.

The banking sector risk assessment includes a top-down balance sheet stress test and single-factor shocks carried out by the Banking Supervision Department (BSD) of the Bank of Israel (BOI), and a contingent claims analysis (CCA) stress test carried out by BOI and IMF staff. Three macroeconomic scenarios were used, a base case, and two shock scenariosAdverse 1 scenario representing a large domestic shock and Adverse 2 scenario representing a serious international and domestic shock. The macro scenarios include projections of GDP, inflation, interest rates, equity prices, and several bond prices. The baseline is as of end-June 2011 and the stress tests horizon goes to end-2014.

Balance sheet stress tests used supervisory data. Satellite models cover housing and corporate credit, household non-housing credit, profit components, profit retention behavior, and haircut models of government and financial institution bonds. Single-factor tests were conducted to estimate vulnerabilities to market risk (interest rate, exchange rate, and stock market shocks) and an idiosyncratic credit shock from exposures to the largest borrower groups and the three largest corporate borrowers. The hurdle rate for the total capital adequacy ratio (CAR) was 9 percent, and that for CT1 was 5 percent (similar to those used in comparable recent FSAPs); profitability too was used as a metric.

The balance sheet stress test results show the banks have sufficient buffers and banks' capital remains adequate under the Base, Adverse 1, and Adverse 2 scenarios. Despite a sharp downturn in growth under Adverse 2 scenario, banks' capital ratios remain broadly adequate, but some make losses, and much of earnings need to be retained; one bank's core tier 1 (CT1) capital ratio falls to 6.9 percent. The reasons for the positive results, even in the Adverse 2 scenario, appear to be the relatively comfortable initial capitalization and profitability. There is very low housing default risk due to low loan-to-value (LTV) ratios, and the fact that mortgages carry recourse. Another reason for the positive results is the favorable starting point for corporate credit losses, which reflects recent strong corporate performance. Also, there is negligible direct exposure to European sovereign risk. In addition, there are no large changes in risk-weighted assets (RWA) because banks are under the standardized approach to setting risk weights.

Single factor shock results show the largest impacts on capital come from a credit shock from each bank's largest borrower group and also the impact of a credit shock of the 
largest three individual borrowers is significant for several banks. This result confirms concern that concentration risk is significant. Bank exposures to European sovereigns are very small and have a negligible impact.

The CCA uses risk-adjusted balance sheets of banks calibrated on market and accounting information, which captures the relationships between changes in market capital, bank assets, and bank credit risk. Econometric analysis links the macro variables to default probabilities and asset price changes, and then the three scenarios were used to project the default probabilities, expected losses, and credit spreads for banks individually and then aggregated.

The results of the CCA analysis are consistent with the balance sheet stress test results. Under the Base scenario, banks' credit spreads are projected at 75 to $210 \mathrm{bps}$ from 2010 through 2014. Somewhat higher levels are projected under the Adverse 1 scenario. Under the Adverse 2 scenario, banks' projected credit spreads increase to levels slightly higher than those seen during the worst periods of the financial crisis in 2008/09; the maximum spread is over 300 bps (300 bps is the highest level for any bank in 2008). Correspondingly, the estimated total potential losses to bank creditors GDP under the Adverse 2 scenario increase to about 1.3 percent of GDP (from about 0.4 percent now), which is low relative to projections for comparable countries. This can be interpreted as a measure of the potential contingent liability of the government to the banking system.

The bank liquidity test involved various shocks to assets and liabilities; the metrics were the BOI prudential ratios for overall and foreign currency liquidity. Results show that all the major banks would be able to maintain the liquidity ratio above unity under strong stress scenarios. However, some banks would not be able to maintain an excess of foreign currency short-term assets over liabilities. Because banks do not rely on market funding and hold relatively few securities, deposit outflows are potentially the main source of risk to liquidity.

Insurance and pension fund stress tests were carried out, differentiating different types of liabilities depending on whether insurance companies or policy holders bear the risks. The results of the shocks on the long-term savings (LTS) products show manageable effects. The stress test applied to the insurance business excluding the saving products did not expose large vulnerabilities. Market risk remains dominant, but two companies face challenges to meet the new, higher capital requirements. Nonetheless, additional work is needed in preparation for Solvency 2, for example, in terms of estimating parameters and calibrating risks.

Any realization of low probability but extreme tail risks from regional geopolitical risks or shock from serious economic crisis in developed economies would pose a challenge, and the authorities need to remain vigilant. Stress tests rely on historical relationships of macro data to risk parameters which may not be representative of future relationships (i.e., there is model risk). Going forward, improvements in solvency and liquidity stress testing procedures should be 
continued. In the area of corporate credit risk, stress testing satellite models using corporate sector expected default frequencies (EDFs) and enhanced macro model linkages would be desirable, improvements on stress testing credit risk and concentration, MOF and BOI increased collaboration on integrated bank and insurance company stress testing. This should be carried out in a way to better understand systemic risk and help guide micro and macroprudential policies. 


\section{BACKground on BANKIng, InSURANCE, HOUSEHOLd, AND CoRporate SECTOR STRUCTURE AND RISKS ${ }^{1}$}

1. The main financial institutions are banks and insurance companies; there is a large and active market in shares, corporate bonds, and government bonds; savers have available a variety of pension, provident, and mutual funds. Starting from the time of the Bachar reform in mid-2005, banks divested most non-commercial banking activities, such as insurance, pension, and provident funds; the banks today focus on traditional banking business. ${ }^{2}$ As a result, the non-bank financial sector has grown rapidly, now playing a large role in credit markets. Most institutions have relatively little overseas activity. Foreign institutions play a minor role. The banking and insurance sectors are concentrated, as can be seen in Figure 1.

\section{Household and Corporate Sector}

2. Households have relatively little mortgage or consumer debt, and their financial assets have built up strongly in recent years. A large share of both assets and liabilities are indexed or carry a variable interest rate. Mortgage loans have not generated significant losses for banks in the past decade: a mortgage loan carries recourse, and a borrower is liable, even after a default and foreclosure procedure has been initiated by the lender. Banks typically maintain close customer relationships with a borrower, and have access to borrowers' income and financial situations. A relatively low loan-to-value ratio would also help banks from incurring losses in case of mortgage loan default. (See top two panels of Figure 2).

\section{House prices have risen sharply since 2008, but leveled off from mid-2011.}

Residential construction has boomed, and mortgage lending has increased rapidly. By the middle of 2009, there were signs of deterioration in mortgage lending standards-such as an increase in unindexed floating rate mortgage loans-and the authorities introduced prudential and other measures to contain risks that were building up, including higher capital requirements for housing loans, supplemental reserve requirements, and variable interest rate mortgage limits.

4. The corporate sector is recovering from the 2008- 09 global crises. Recovery from the crisis was quick, but profitability has not reached pre-crisis levels (see Figure 2 bottom four panels). Market indicators for corporate default probability have begun to rise, though they are still below 2008-09 levels. Corporate sector leverage (a measure of debt to market

\footnotetext{
${ }^{1}$ This note was prepared by Dale Gray (IMF), banking system stress testsing, and Rodolfo Wehrhahn (IMF) and Lawrie Savage (Supervisory Consultant) on the insurance sector stress testing. We would like to thank counterparts in the $\mathrm{BOI}$ and $\mathrm{MOF}$ for their assistance, insights and valuable suggestions.

${ }^{2}$ Each of five largest banking institutions in Israel represents a "bank holding company," and typically comprises the main bank, one or more wholly-owned boutique banks, and a series of non-bank financial subsidiaries, held either in Israel or abroad.
} 
value of assets) increased during the crisis, declined in 2010 but has increased again in 2011. The median default probabilities by corporate sector are shown in Figure 2; the construction and consumer goods sectors have the highest estimated default probabilities.

\section{Israel's corporate sector is highly concentrated and dominated by certain large}

conglomerate groups. For example, the turnover of the six largest groups accounts for about a quarter of GDP. These conglomerates substantially increased leverage prior to the crisis. A Prime Minister committee to address Israeli business structure recently presented its recommendations, such as prohibiting the control of both large financial and real entities and strengthening of corporate governance. 
Figure 1. Israel: Banks and Insurance Companies

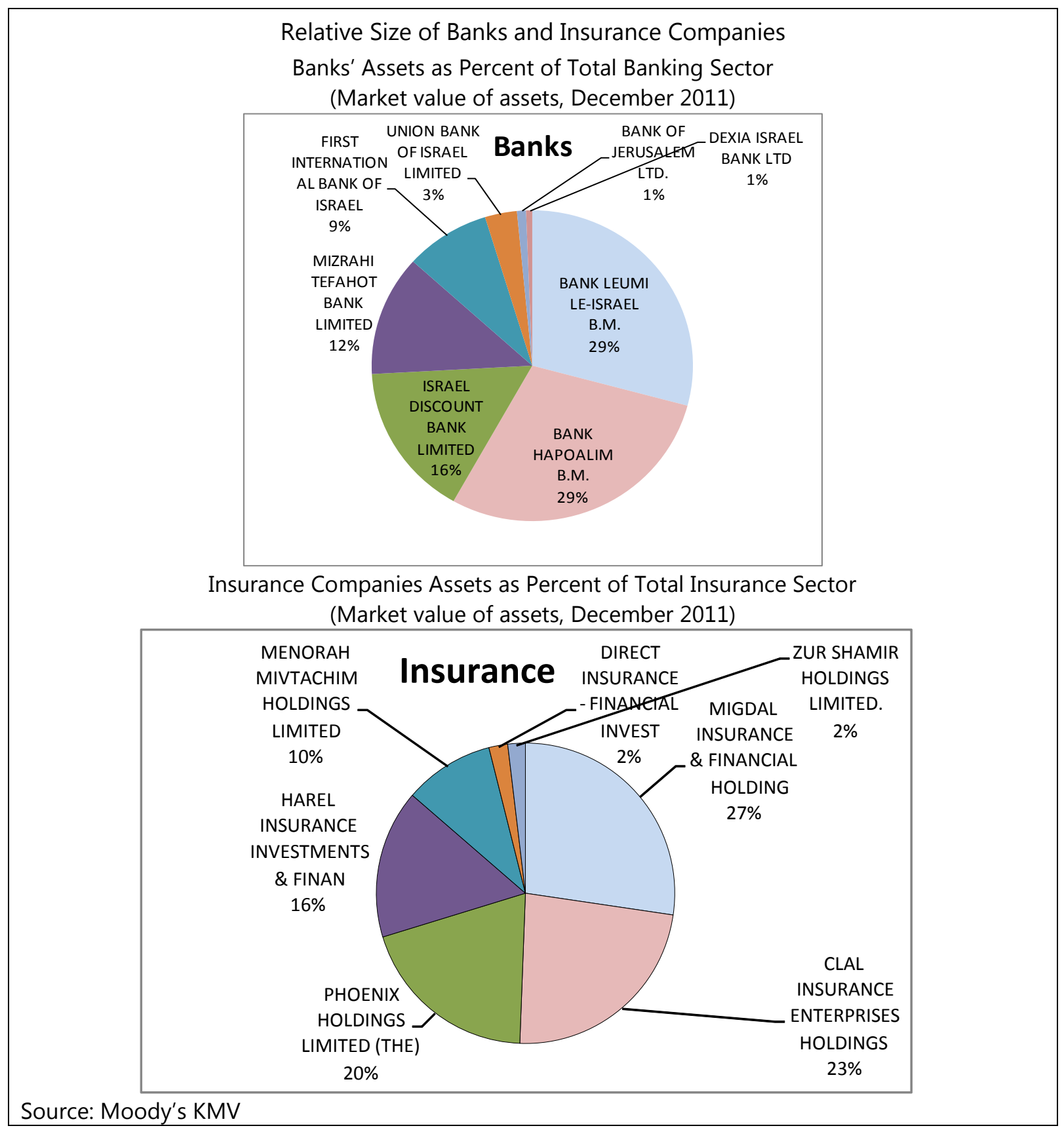


Figure 2. Israel: Household and Corporate Sector Indicators
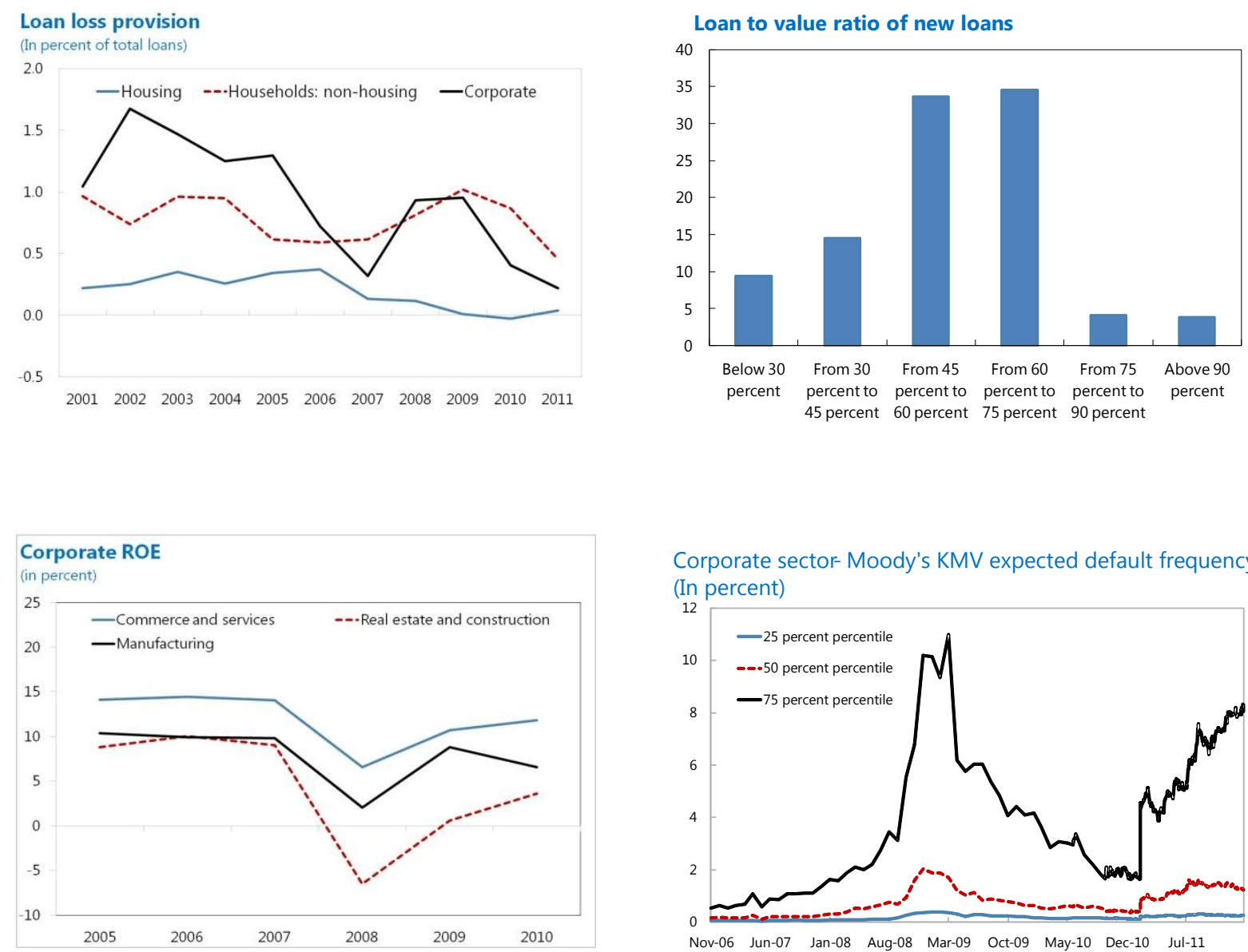

Corporate sector Moody's KMV expected default frequency (In percent)

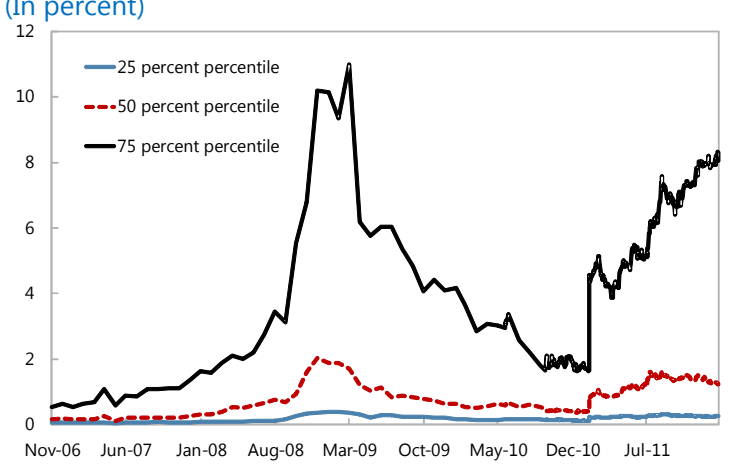

Corporate sector - Moody's KMV market leverage indicator

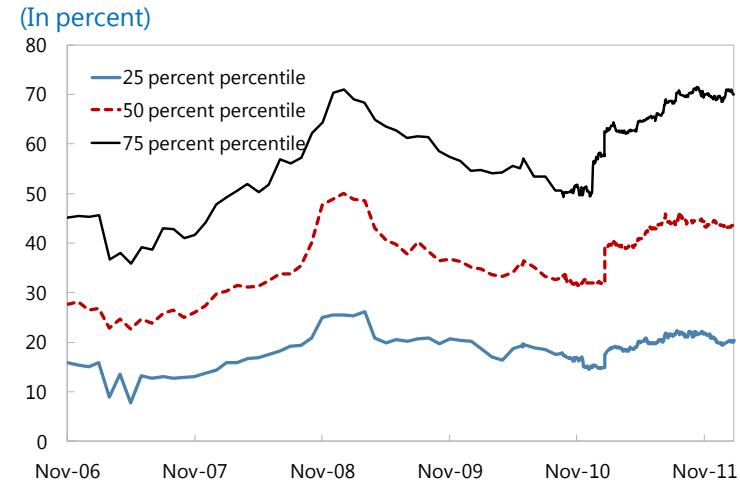

Moody's KMV expected defualt frequecy by industry (In percent)

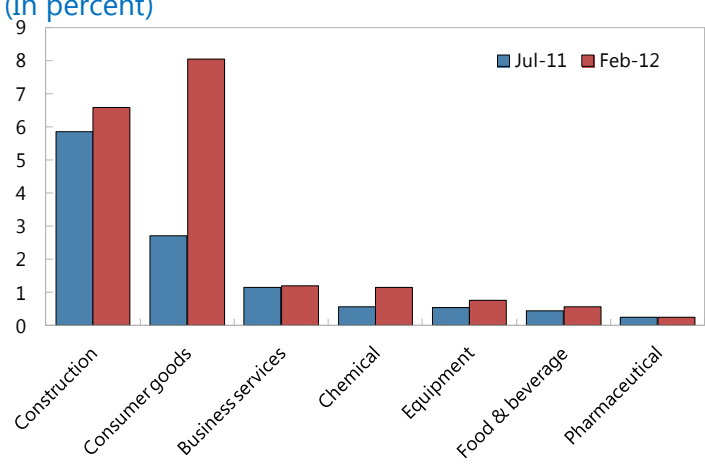

Sources: BOI, Haver, Moody's KMV, and IMF staff calculation. 


\section{MACROECONOMIC SCENARIOS FOR BANK STRESS TESTING}

6. The bank solvency tests are based on three scenarios that reflect key macroeconomic and financial risks, particularly a domestic slowdown and the potential impact on the Israeli economy and banks of a European crisis and US slowdown:

- $\quad$ The Base scenario is based on the BOI staff forecast and reflects the forecasted path of the economy. It relies on the BOI DSGE model combined with a judgment procedure and is more conservative than the IMF WEO October 2011 forecast.

- Adverse scenario 1 is a domestic recession, caused by geopolitical concerns leading to an economic disruption, declining demand, an increase in unemployment, and a rising risk premium. Real GDP declines relative to the baseline slightly less than one standard deviation.

- Adverse scenario 2 reflects a global recession and difficulties in Europe which affects the Israeli economy sharply. Real GDP declines relative to the baseline by about $2 \frac{1}{2}$ standard deviations.

7. The approaches to forecasting the main macroeconomic variables can be summarized as follows:

- GDP Growth: The GDP growth values for the baseline scenario are the output of the DSGE model and fit the baseline scenario of the Research Department Staff Forecast; the values for Adverse scenario 1 and 2 were agreed with the IMF FSAP team, the $\mathrm{RD}$ and the BSD. The first 6 quarters of the Adverse scenario 2 (2011Q4 - 2013Q1) were based on the growth path observed in the 2008 crisis with the 2 quarters of GDP contraction seen in the 2008-2009 crisis, extended to 4 quarters of contraction.

- Inflation, Exchange Rate Depreciation, BOI Short Interest Rate and

Unemployment: These 4 variables are the output of the RD staff forecast after setting the GDP growth path and the relevant shocks (risk premium, global recession).

- $\quad$ TA100 Stock Index: For the baseline scenario, the RD used a VAR model that includes domestic (growth, inflation, depreciation, BOI interest rate and changes in TA100) and foreign variables (world growth, inflation, short interest rate, changes in S\&P500 and the VIX). For Adverse scenario 1, changes observed at the 2001 recession were used (which was a domestic recession). For Adverse scenario 2, the changes observed during the 2008 crisis were used (in accordance with the exercise preformed with the GDP growth).

- Long-Term and Short-Term Yield Spread: The projections for this variable were based on historical data. For the baseline scenario the long-term yield on government bonds was set at an average rate (5 percent), since it reflects an average growth. For 
Adverse scenario 1, the historical spreads observed at the 2001 recession were used. It was assumed the long-term yield would converge towards the above mentioned average rate of 5 percent in the last 6 quarters of the scenario. For Adverse scenario 2, the historical spreads observed at the 2008 crisis were used as a guide. (Bond ratings are Israeli ratings, not international ratings.)

The full set of scenario values are in Table 1: 
Table 1. Israel: Stress Testing Scenario Parameters

(In percent)

\begin{tabular}{|c|c|c|c|c|c|}
\hline & & 2011 & 2012 & 2013 & 2014 \\
\hline \multirow[t]{3}{*}{ Real GDP Growth } & Base & 3.6 & 3.1 & 3.4 & 3.7 \\
\hline & Adv. 1 & 3.4 & 1.2 & 2.5 & 2.8 \\
\hline & Adv. 2 & 1.9 & -2.8 & 1.2 & 2.5 \\
\hline \multirow[t]{3}{*}{ Inflation } & Base & 3.0 & 2.3 & 2.2 & 1.8 \\
\hline & Adv. 1 & 3.1 & 3.2 & 2.8 & 3.1 \\
\hline & Adv. 2 & 2.8 & 0.6 & -1.4 & -4.8 \\
\hline \multirow[t]{3}{*}{ Exchange Rate Depreciation } & Base & 3.0 & 1.7 & 1.3 & -0.4 \\
\hline & Adv. 1 & 4.1 & 6.8 & 3.6 & 1.2 \\
\hline & Adv. 2 & 3.6 & 12.0 & -1.2 & -8.3 \\
\hline \multirow{3}{*}{ Bank of Israel interest rate } & Base & 3.0 & 3.0 & 2.8 & 2.3 \\
\hline & Adv. 1 & 3.1 & 3.6 & 2.6 & 2.1 \\
\hline & Adv. 2 & 2.9 & 1.0 & 0.5 & 0.5 \\
\hline \multirow{3}{*}{ Unemployment } & Base & 5.6 & 5.7 & 5.9 & 6.1 \\
\hline & Adv. 1 & 5.7 & 6.5 & 7.3 & 7.3 \\
\hline & Adv. 2 & 5.9 & 9.9 & 11.1 & 10.8 \\
\hline \multirow[t]{3}{*}{ Change in TA100 Index } & Base & -24.9 & -1.6 & -0.2 & 7.5 \\
\hline & Adv. 1 & -30.7 & -8.7 & -25.6 & 7.5 \\
\hline & Adv. 2 & -36.4 & -57.3 & 33.9 & 21.7 \\
\hline \multirow{3}{*}{ Long term-Short term Yield Spread } & Base & 1.9 & 2.0 & 2.2 & 2.7 \\
\hline & Adv. 1 & 2.2 & 3.3 & 3.2 & 3.0 \\
\hline & Adv. 2 & 2.2 & 5.6 & 4.7 & 4.1 \\
\hline \multirow[t]{3}{*}{ AA rated bonds spread } & Base & 1.1 & 1.2 & 1.2 & 1.2 \\
\hline & Adv. 1 & 1.1 & 2.2 & 1.7 & 1.7 \\
\hline & Adv. 2 & 1.3 & 3.1 & 2.2 & 1.7 \\
\hline \multirow[t]{3}{*}{ A rated bonds spread } & Base & 2.7 & 3.4 & 3.4 & 3.4 \\
\hline & Adv. 1 & 2.7 & 6.8 & 4.8 & 4.8 \\
\hline & Adv. 2 & 3.3 & 12.3 & 6.8 & 4.8 \\
\hline \multirow[t]{3}{*}{ BBB rated bonds spread } & Base & 6.1 & 7.8 & 7.8 & 7.8 \\
\hline & Adv. 1 & 6.1 & 16.0 & 12.5 & 12.5 \\
\hline & Adv. 2 & 7.7 & 25.7 & 16.0 & 12.5 \\
\hline \multirow[t]{3}{*}{ Non-rated bonds spread } & Base & 7.7 & 8.9 & 8.9 & 8.9 \\
\hline & Adv. 1 & 7.7 & 17.3 & 16.5 & 16.5 \\
\hline & Adv. 2 & 9.7 & 22.7 & 17.3 & 16.5 \\
\hline \multirow[t]{3}{*}{ Real estate sector bonds spread } & Base & 4.7 & 5.6 & 5.6 & 5.6 \\
\hline & Adv. 1 & 4.7 & 9.6 & 9.0 & 9.0 \\
\hline & Adv. 2 & 5.2 & 15.7 & 9.6 & 9.0 \\
\hline
\end{tabular}

Source: Bank of Israel 


\section{Top-Down Balance SheEt Solvency STRESS TeStS FOR BAnKS}

\section{A. Stress Testing by the BSD}

8. Stress test (ST) modeling has improved considerably over the last few years. Significant progress has been made in BSD concerning ST in the last few years, including through the development of satellite models and the calibration of stress tests. Stress tests are conducted in the BSD on a regular basis as well as on an ad hoc basis for specific or systemic purposes, and are used to evaluate weaknesses and vulnerabilities of the banks and also in determining the capital adequacy required of the banking system. There has been progress constructing satellite models of credit risk for corporate sector and for construction and real estate. Stress tests involving the credit risk impact of collapse of two big borrower groups, as well as stress tests of exposure to borrowers who issued bonds in the Israeli bond market were carried out.

9. A severe global stress test scenario was carried out in 2010. The global stress scenario analysis was a one-time analysis done for a specific purpose. It is a very severe scenario based on 2008 crisis severity. Securities credit losses and default probabilities were severe. This was done to be able to look at how risk factors may affect banks and drill down on what might happen in "worse case" scenario. Results showed the banks to be resilient to these global shocks. However, the scenario highlighted the need for a further strengthening of Core Tier 1 capital, and for enhancing risk management and the controls over risk-oriented activities, such as securities activity and leveraged credit, as well as the controls applied with respect to the concentration of borrower groups.

10. Beginning in the second half of 2010, the BSD together with the BOI Research Department (RD) agreed on a program of regular stress testing going forward. This includes enhancing stress testing models, more focus on corporate sector credit risks, concentration/group risk, and supporting macroprudential risk and policy analysis.

\section{B. Assumptions for the FSAP Update Bank Balance Sheet Stress Tests}

11. The banking stress test exercise focused on the largest five banks in Israel. These banks comprise 95 percent of the system, based on asset size. The banks are Bank Leumi LeIsrael, Bank Hapoalim, Israel Discount Bank, Mizrahi Tefahot Bank, and First International Bank of Israel.

12. The banking sector risk assessment includes a top-down balance sheet stress test and single factor tests carried out by the BSD. Balance sheet stress tests used supervisory data. These tests rely on BSD supervisory stress testing methods and models of banks' balance sheets and profit and loss results. The tests are based on end-June 2011 balance sheets. The projection period is until end-2014, with outputs for end-2011, end-2012, end2013, and end-2014. The projected macroeconomic variables and other assumptions affect loan quality and provisioning, and other elements of their performance. Satellite models 
cover housing and corporate credit, household non-housing credit, profit components, profit retention behavior, and haircut models of government and foreign financial institution bonds. Single factor tests were conducted to estimate vulnerabilities to market risk (interest rate, exchange rate, and stock market shocks) and an idiosyncratic credit shock from exposures to largest borrower group and three largest corporate borrowers. The hurdle rate for the total capital adequacy ratio (CAR) was 9 percent, and that for CT1 was 5 percent (similar to those used in comparable recent FSAPs); profitability too was used as a metric.

\section{Main Satellite Models}

\section{The BSD used six satellite models for the stress test to model profits and credit}

losses. The model for profits used three satellite models; for net interest income, for operating and other income, and for operating and other expenses. The profit model was first estimated for the aggregate results of the five banks then modified to fit each individual bank with adjustments based on average profitability of each bank. The satellite models used are described in more detail in Appendix II. The satellite model for housing credit losses estimates loan loss provisions as a function of unemployment, BOI interest rate and lagged loan loss provisions. Another satellite model was used for households' non-housing credit: loan loss provisions for this category are a function of unemployment and changes in financial assets of households driven primarily by the changes in the Tel Aviv 100 index. Corporate (business) sector losses is based on a "quasi-probability of default," which is obtained by dividing the number of firms that has made a loan-loss provision by the number of active firms during that period (this is not the common definition of a probability of default - PD — but rather an approximation of the probability of reaching a loan loss provision threshold). This quasi-probability of default is linked to macro variables including the Composite Index (an index used by BSD as a proxy for GDP which has a high correlation with GDP), real interest rates, and changes in the TA100. ${ }^{3}$ Losses of the corporate sector model in Adverse scenario 1 and scenario 2 were based on 99th percentile of the quasi-PD distribution. In the view of the BSD, the $99^{\text {th }}$ percentile is a conservative assumption, as is the conservative loss given default (LGD) assumption (0.45).

\footnotetext{
${ }^{3}$ To get the final loss rates for the scenario there is a factor calibration factor (ratio between average provisions and average losses) which ends up adjusting for the "high" quasi-PD.
} 


\section{Other Elements of Balance Sheet Stress Tests}

\section{Dividend pay-out rule}

14. Dividend pay-out rule is modeled explicitly. BSD used information from historical ROE and dividend pay-outs, based on this analysis it set a dividend policy that takes into account both ROE and the level of core Tier1 capital ratio:

- Dividends will be distributed only if the ROE is higher than 6 percent and core Tier1 capital ratio is above 8 percent (after distribution).

- The dividend rate is set to 35 percent for core Tier 1 capital ratio above 8 percent but below 8.5 percent.

- For a core capital ratio above 8.5 percent the dividend rate is set to 50 percent.

A profit tax rate of 40 percent was applied.

Balance sheet growth, risk-weighted assets, haircuts on sovereign debt.

15. The exercise assumed zero balance sheet growth. The assumption is of zero growth

rates in assets. Since the beginning of the previous decade, balance sheet growth of banks has been low (partly reflecting the rapid corporate bond market expansion). For the scenarios where there is a decline in nominal GDP, constant balance sheet growth is a conservative assumption.

16. Risk-weighted assets change according to standardized approach rules. As banks are all under the standardized approach, the estimated impact of exchange rate changes on risk weighted assets was used (according to standardized approach rules). This estimate is based on a methodology we developed, that takes into account each bank's foreign currency denominated assets and their average weight risk.

17. BOI staff estimated haircuts on sovereign debt. Nearly all sovereign debt is Israeli government debt, with a very small amount of debt of other sovereigns. The BOI staff estimated the haircuts on Israeli government debt for the three scenarios which was discussed and agreed with the FSAP mission. Relatively small amount for debt from foreign financial institutions is held by banks, RD and BSD used ratings and default probabilities to estimate what seem to be reasonable haircuts on this debt. (The haircut assumptions on both these types of debt are described in Appendix II). The quantity of European periphery sovereign debt is negligible.

\section{E. Results of Balance Sheet Stress Tests}

The balance sheet stress test results show the banks have sufficient buffers and banks' capital remains adequately capitalized under the Base, Adverse 1 and 2 scenarios 
(Figure 3). Despite a sharp downturn in growth under Adverse scenario 2, banks' capital ratios remain above the hurdle rates, but some make losses, and much of earnings need to be retained. Under Adverse scenario 2, one bank had a CT1 of 6.9 percent in 2012. The reasons for the positive results, even in the Adverse 2 scenario, appear to be the relatively comfortable initial capitalization and profitability. There is very low housing default risk due to low LTVs due to the fact that mortgages carry recourse. Another reason for the positive results is the favorable starting point for corporate credit losses, which reflects recent strong corporate performance. Also, there is negligible exposure to European sovereigns and limited bank risks. In addition, there are no large changes in RWA because banks are under the standardized approach. ${ }^{4}$

\footnotetext{
${ }^{4}$ There is small reduction in RWA due to exchange rate effects under the standardized approach rules.
} 
Figure 3. Israel: Bank Balance Sheet Stress Test Results (Maximum, unweighted mean, and minimum)
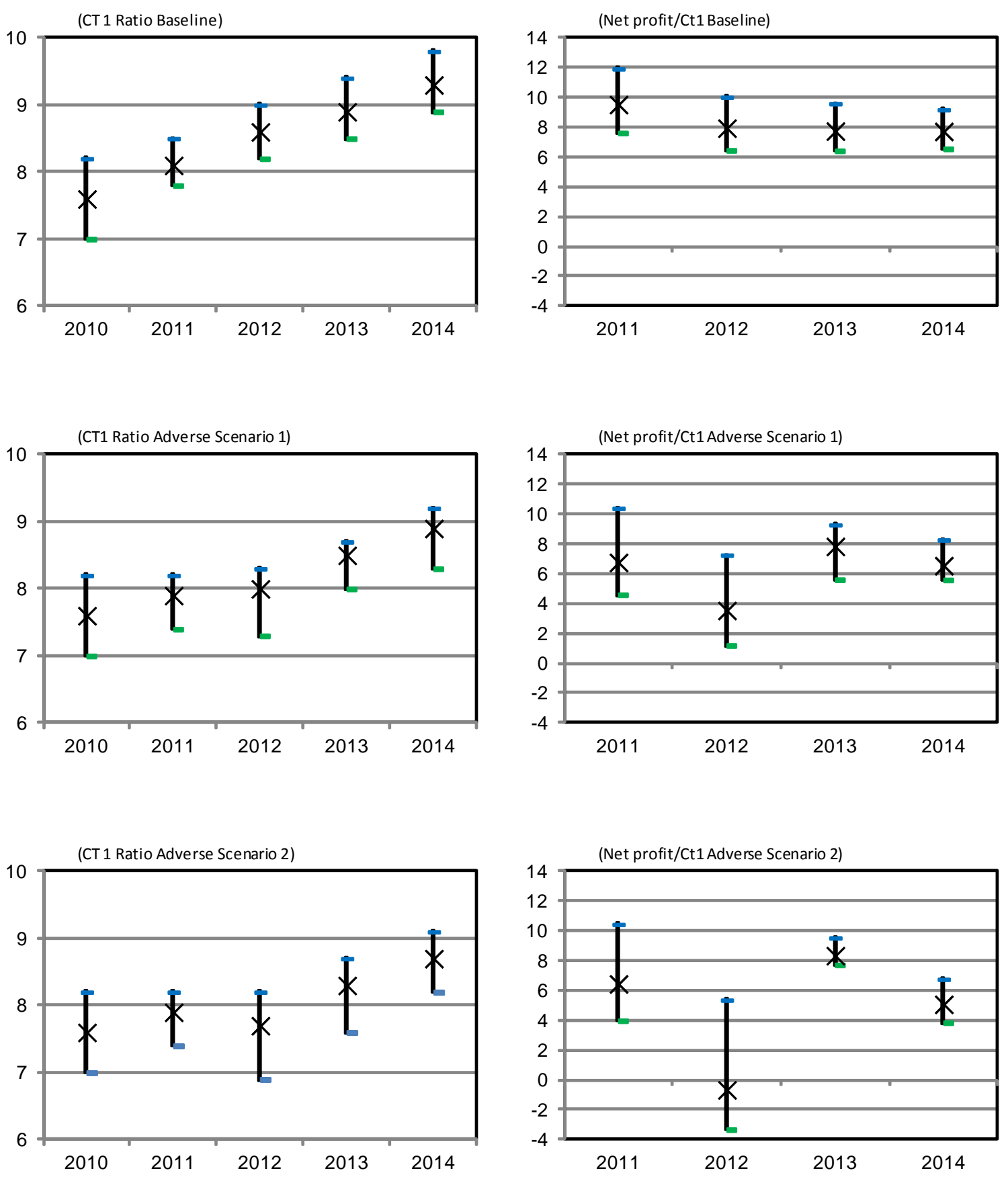

Source: BOI, and staff estimates. 


\section{F. Single Factor Tests}

18. Single factor shock results show that concentration risk has the largest potential impact on capital (see stress testing summary table in Appendix I). The largest impacts on capital come from a credit shock from each bank's largest borrower group, and also the impact of a credit shock of the largest three individual borrowers is significant for several banks. This result confirms the concern that concentration risk is significant. Exposures to European sovereign have a negligible impact.

\section{Sensitivity analysis results - Single Factor (smallest to largest impact as percent CT1)}

- Credit shock largest borrower group: Impact is 8.5 to 12.6 percent of CT1

- Credit shock largest three borrowers: Impact is 4.3 to 6.6 percent of CT1

- Stock market decline of 25 percent: Impact is 0.3 to 3.8 percent of CT1

- Exchange rate depreciation of 15 percent: Impact is 0.2 to 3.1 percent of CT1

- Interest rate increase: Impact is -5.0 to 5.0 percent of $\mathrm{CT} 1^{5}$

- Interest rate decrease: Impact is - -4.8 to 4.7 percent of CT1

- European peripheral exposures: Impact is 0.4 to 1.4 percent of CT1

19. Balance sheet stress tests and single factor tests come with some caveats. The balance sheet stress tests rely on historical relationships of macro data to risk parameters which may not be representative of future relationships (i.e., there is model risk). Going forward, improvements in stress testing procedures should be continued. In the area of corporate credit risk stress testing satellite models using corporate sector EDFs and enhanced macro model linkages would be desirable, as is related improvements on stress testing credit risk and concentration.

\section{Top-Down Contingent Claims Analysis Stress Tests for Banks}

20. CCA framework is a risk-adjusted balance sheet concept. It is an integrated framework relating bank asset values to equity value, default risk and bank funding costs. In the risk-adjusted balance sheet framework, the total market value of bank assets is equal to

\footnotetext{
5 The result shows the effect of hypothetical changes in interest rates on the net fair value of financial instruments of a bank on consolidated basis, as of June 30, 2011, according to the BSD reporting to the Public Directive 630.
} 
the sum of its market value equity and its "risky debt" over a specific time horizon. ${ }^{6}$ Risky debt is composed of two parts, the default-free value of debt and deposits minus the "expected loss to bank creditors" from default over a specific time horizon (see Appendix III). Note that CCA type models for corporates, such as MKMV, are frequently used to estimate PDs and LGDs; see Box 1.

\section{Box 1. MKMV CCA Model Calibration and Calculation of EDFs and Fair Value Spreads}

In the 1990s a company called KMV adapted Merton's CCA approach for commercial applications to estimate Expected Default Probabilities (EDFTM). KMV was purchased by Moody's in 2002 and is now MKMV. The exact methodology is confidential, but general descriptions are in KMV (2001), MKMV (2003), Bohn (2000), and Crouhy et. al. (2000). MKMV's EDF credit measure is calculated using an iterative procedure to solve for the implied asset volatility. It uses an initial guess of volatility to determine asset value and de-lever the equity returns. The volatility of the asset returns are used as an input into the next iteration of asset values and asset returns until a convergence is obtained. In essence, the model used equity return volatility, equity values, distress barrier from book value of liabilities, and time horizon to get a distance-to-distress. This distance-to-distress was then mapped to actual default probabilities, called EDFs (expected default probabilities), using a database of detailed real world default probabilities for many firms. MKMV estimates the "actual" default probabilities and CCA parameters daily for 88 financial institutions and 220 corporates in Israel. Robustness checks show the model to be quite accurate and it is a leading indicator for default, for example high yield default forecasts, according to MKMV EDFs, lead actual default rates by about a year. (For sectors (groups of firms or banks) the time series of median $\left(50^{\text {th }}\right.$ percentile) EDFs by number of firms and other percentiles are calculated.)

After the EDF is calculated, credit spreads are then calculated in three steps. The EDF is converted into a risk-neutral default probability (RNDP) by combining the EDF estimate with the market price of risk (empirical parameters the capture changing risk appetite in markets). Then a sector wide bank LGD is used and then the Fair-Value Credit Default Swap spread is calculated (FVCDS) which is a fair value credit spread given the bank's credit risk in the absence of government guarantees or market illiquidity. It has the advantage of being an understandable credit indicator that can be compared across time and across institutions.

\section{In the risk-adjusted balance sheet approach, changes in assets are directly linked to changes in market value of equity and the expected losses to creditors. For a bank the} key risk-adjusted balance sheet relationships are:

\footnotetext{
${ }^{6}$ Contingent claims analysis (CCA) is a generalization of the option pricing theory pioneered by Black and Scholes (1973), as well as Merton (1973). The values of liabilities (equity and risky debt) derive their value from assets; they are contingent claims on assets. When applied to the analysis of credit risk, it is commonly called the Merton Model which is based on the Black-Scholes-Merton (BSM) framework of capital structurebased option pricing theory (Merton,1974).
} 
Bank assets $=$ Bank market value of equity + Bank risky debt and deposits

where,

Bank risky debt and deposits $=$ Default-free value of debt and deposits -

Expected losses to bank creditors

In the risk-adjusted balance sheet framework, a decline in the value of assets leads to less than one-to-one decline in the market value of equity; the amount of change in equity depends on the degree of financial distress in the bank. The decline in bank assets simultaneously leads to an increase in the value of expected losses to creditors. The amount of increase can be very high when banks are in severe financial distress.

\begin{tabular}{ll}
\hline & Risk-adjusted (CCA) Bank Balance Sheet \\
Assets & Liabilities \\
Market Value of Assets & Risky Debt \\
(Cash, Reserves, Value of "Risky" & (= Default-free Value of Debt and Deposits minus \\
Assets) & Expected Losses to Bank Creditors) \\
& Market Value of Equity \\
\hline
\end{tabular}

22. In the risk-adjusted (CCA) balance sheet of the bank, the "expected loss to bank creditors" relates to the total debt and deposits on the full bank balance sheet. This expected loss to bank creditors can be viewed as a probability of bank default times a loss given default times an "exposure" represented by the default free value of the bank's total debt and deposits (formula is in Appendix III). The expected loss to creditors is a "risk exposure" in the risk-adjusted balance sheet. Note that the risk-adjusted bank balance sheet and the traditional accounting bank balance sheet are related: the accounting balance sheet can be "derived" from the special case of the risk-adjusted balance sheet - the case where there is uncertainty is set to zero (i.e., bank's assets have no volatility). With zero volatility on the balance sheet, the expected loss to bank creditors goes to zero and equity becomes book equity. The "risk exposure" becomes zero. ${ }^{7}$

\section{The risk-adjusted (CCA) balance sheet of the banks quantifies relationship of market capital level, default probability and bank credit spreads, as well as the impact of changes in global risk appetite.}

- $\quad$ Lower levels of the market value of equity (market capitalization) are directly related to higher bank default probabilities. There is increasing interest in indicators that use market value of equity as measures of financial fragility.

\footnotetext{
${ }^{7}$ See Gray, Merton, Bodie (2007 and 2008), and Gray and Malone (2008).
} 
- $\quad$ The impact of changes in global or regional risk appetite on the values of bank expected losses to creditors, bank funding costs, and bank equity can be measured in the CCA approach. Lower risk appetite causes investor to flee from "risky" investments to safer forms of investment, this raises borrowing costs around the world for corporate, sovereign, household borrowers etc. Since the CCA framework quantifies the impact of changes in risk appetite stress test scenarios can include stressing changes global or region risk appetite.

- $\quad$ MKMV uses a version of CCA models and provides daily estimates of EDFs and CCA parameters for all major Israeli banks and insurance companies (and corporate). Box 1 described the MKMV data used as in input to the stress test exercise.

\section{Linking Macro Variables to Financials Institutions' CCA Outputs - Methodology}

24. The CCA banking stress test exercise focus on the largest five banks in Israel, as in the balance sheet stress test exercise. These banks comprise 95 percent of the system, based on asset size. The banks are Bank Leumi Le-Israel, Bank Hapoalim, Israel Discount Bank, Mizrahi Tefahot Bank, and First International Bank of Israel.

25. In order to understand the relationship between different banks MKMV data and the macroeconomic environment, the BOI RD developed an econometric model to explain the changes in the bank EDFs and asset return. The model for each institution can be represented by:

$$
y_{i t}=\alpha_{i}+\beta_{i} X_{t}+\varepsilon_{i t}
$$

where $y_{i t}$ is the change in the EDF of institution $i$ or the change in the log of the assets (assets return) and $X_{t}$ is a set of macro variables. As it will be explained shortly, since the sample for each institution is small, we estimated the model in a panel version, so the model that was estimated was:

$$
y_{i t}=\alpha_{i}+\beta_{i} X_{t}+\gamma_{i}+\delta_{i} I_{i} * \bar{X}_{t}+\varepsilon_{i t}
$$

where the $\gamma_{i}$ is a fixed effect for each institution and $I_{i} * \bar{X}_{t}$ is an interaction term between the institution and macro variables, in order to catch different affects of the macro variable on each institution's $y_{i t}$. Of course, if $\bar{X}=X$ then we go back to a unique model for each institution which cannot be estimated due to a small sample. Therefore, the decision on which macro variable to include in $\bar{X}$ was made by trying different specifications and using judgment.

26. The data for estimation of the model consist of the EDFs and asset return for Israel's five largest banks and macro variables. The macro variables are quarterly; RD used the quarterly average of the EDF and the assets of each institution, obtaining a sample at the size of 34 observations at the minimum and 59 at the maximum (1997Q1-2011Q3). The 
macro variables considered were the GDP growth (annual rates, difference from steady state), inflation (annual rates, difference from steady state), depreciation of effective foreign exchange (annual rates, difference from steady state), Bank of Israel short interest rate (annual rates, difference from steady state), TA100 return (annual rates, difference from steady state) and the yield on non-indexed long government bonds (non Indexed, 8-10 years, annual rates) or the gap between this yield and the short interest rate. ${ }^{8}$ The RD used a panel estimation procedure to link the macro factors to the individual bank EDFs and asset return. This estimation process and the econometric results are in Appendix IV. The results show:

- Banks Change in EDF - An increase GDP and increase in the BOI interest rate lowers the EDF, which seems sensible. Coefficients are significant at the 1 percent level. Exchange rate depreciation raises the EDF, probably indicating that, although assets are affected positively by depreciation, liabilities are also increased; in sum the risk is higher. The higher EDF caused by higher long term interest rate needs to be investigated further, although the effect not economically significant. It was also found that TA100 returns affect the institutions differently.

- Banks Assets Returns - All macro variables affect assets return positively and significantly (FX affect is lagged). Positive and significant idiosyncratic effects are observed only in two banks. Various specifications showed no different affect of GDP growth and/or TA100 returns across banks.

\section{In sum, most of the estimation results make sense in terms of their effect and} direction and many are significant at the 1 and 5 percent level. Although we believe that the chosen specifications logically reflect the relationship between the macro variables and the CCA outputs but it would be useful to explore additional specifications and further analysis. Using the macro econometric model the EDFs and asset returns were projected for all five banks until the end of 2014, for all three stress scenarios. A 2-standard-error-of-theprediction confidence interval was calculated for each institution forecast. The EDFs were transformed into fair value credit spreads.

\section{The results of the CCA analysis are consistent with the balance sheet stress test}

results (Figure 4). The CCA analysis provides estimates of CCA fair value credit spread for each bank for each scenario (fair value spread is an estimate of the bank CDS spread, absent liquidity premiums and distortions from government guarantees). As can be seen, the fair value spread at the end of 2008 ranged from 150 to 300 basis points (bps) and declined to below 110 bps in 2010. Under the Base scenario, the spreads increased somewhat to between 75 to 210 bps from 2010 through 2014, and slightly higher level under the Adverse 1 scenario (remaining below 2008 levels). Under the Adverse 2 scenario, the spreads increase

\footnotetext{
${ }^{8}$ In regressions where one of these variables is included the estimation period is shorter since the long term interest rate is available only from mid-2001.
} 
to a higher level than during the worst periods of the financial crisis in 2008/09; the maximum spread is over 300 bps (300 bps is the highest level for any bank in 2008). The CCA results also give an estimate of the total losses to bank creditors for the five largest banks as a percent of GDP. Under the Adverse 2 scenario the total expected losses to bank

Figure 4. Israel: CCA Stress Test Results

(Maximum, mean and minimum fair value bank spreads and banking system expected losses as percent of GDP)
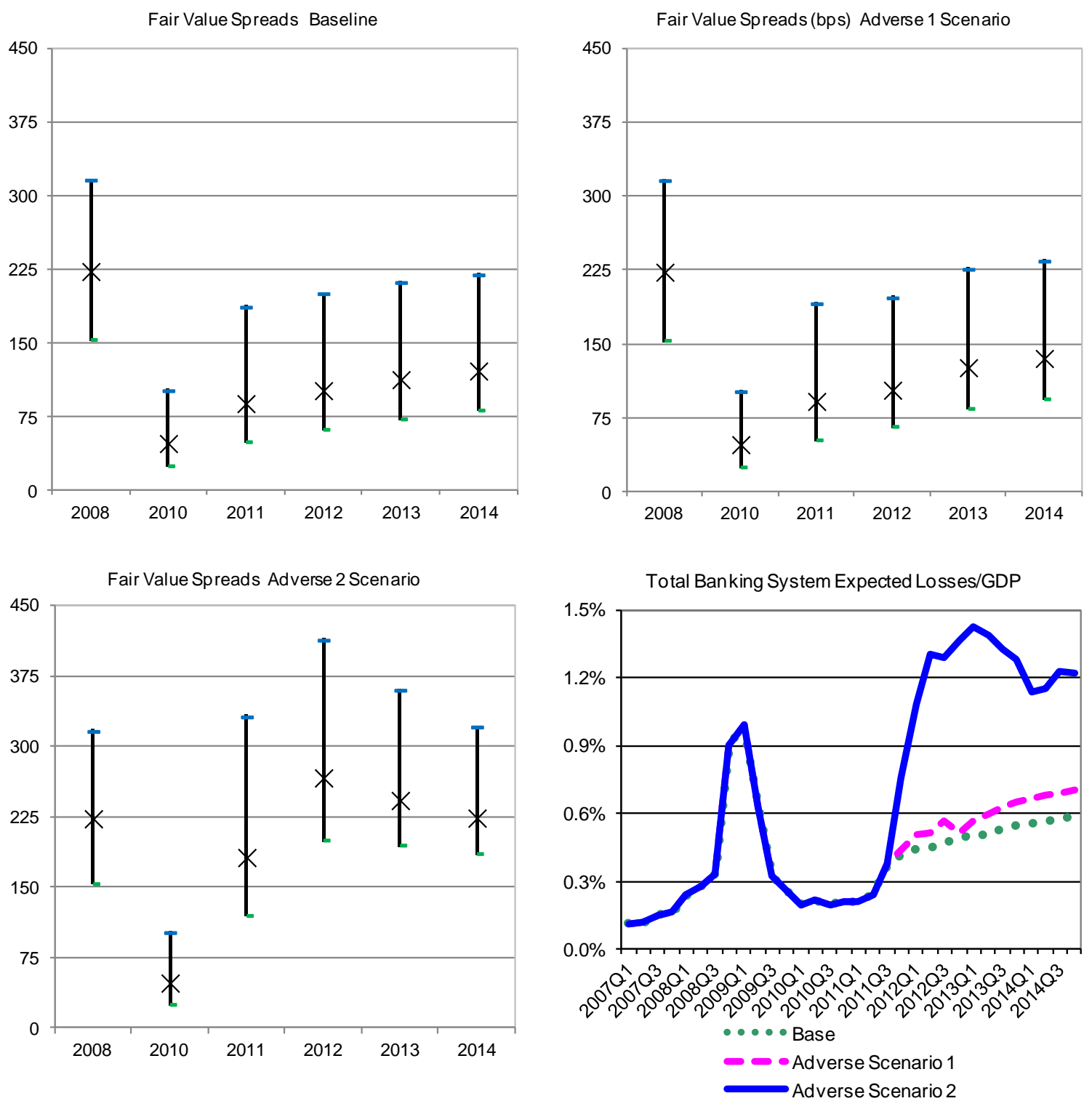

Source: BOI, and staff estimates. 
creditors increases to 1.3 to 1.4 percent of GDP, which is low by comparison to other countries. This can be interpreted as a measure of the potential contingent liability of the government to the banking system. The market capital and regulatory capital shortfalls are different concepts and cannot be compared directly. However, the results of the balance sheet and CCA tests appear to be consistent with each other in the ranking of bank vulnerability. (See Appendix IV for more detailed outputs on past and projected EDFs and spreads).

29. Stress tests using the CCA balance sheets and EDFs come with some caveats. The CCA stress tests rely on historical relationships of macro data to EDF and asset return such relationships may not be representative of future relationships (i.e., there is model risk). The EDF estimates incorporate forward looking equity information but there may be instances of less than liquid equity markets or over/under shooting. Going forward improvements and refinements in CCA stress testing procedures should be continued.

\section{LIQUIDITY STRESS TESTS}

30. Liquidity risk stress tests focused on the change in short-term assets and liabilities based on the BOI's supervisory model. The supervisory model for liquidity uses one month horizon based on end-2011 data (a description of the model in at the end of Appendix II). Liquidity stress tests were carried out by the BSD for four severe stress scenarios, by total currency positions and foreign currency positions, separately. The aim of these stress tests is to ensure that a bank maintains unencumbered and high quality liquid assets above expected liquidity needs for a one month horizon (i.e., the liquidity ratio exceeds unity), even under severe stress scenarios.

\section{The liquidity test results show that all banks would be able to maintain sufficient liquid assets under strong stress scenarios (Table 2). However, for foreign currency liquidity positions alone, some banks would not be able to maintain an excess of foreign currency short-term assets over liabilities. Because banks do not rely on market funding and hold relatively few securities, deposit outflows are potentially the main risk to maintaining liquidity. Liquidity ST analysis seems reasonable and adequate; going forward improvements in liquidity stress testing practices, including extensions of the analysis beyond a one month horizon, should be continued.}


Table 2. Israel: Liquidity Stress Test Results

(Change in ratios unless indicated; based on end-2011 data)

\begin{tabular}{lcc}
\hline & All currencies & $\begin{array}{l}\text { Foreign } \\
\text { currency }\end{array}$ \\
\hline Baseline & 1.63 & 1.59 \\
Average & 1.62 & 1.49 \\
Minimum & 1.48 & 1.04 \\
A 10 percent outflow of short-term deposits & 1.28 & 1.25 \\
Average change from baseline & 0.35 & 0.33 \\
Worst change from baseline & 0.36 & 0.50 \\
A 20 percent outflow of non-resident deposits & 1.53 & 1.30 \\
Average change from baseline & 0.09 & 0.27 \\
Worst change from baseline & 0.12 & 0.50 \\
A bank's largest interbank claim becomes illiquid & 1.61 & 1.52 \\
Average change from baseline & 0.02 & 0.10 \\
Worst change from baseline & 0.04 & 0.16 \\
Short term securities become illiquid/ 1 & 1.57 & 1.38 \\
Average change from baseline & 0.05 & 0.18 \\
Worst change from baseline & 0.10 & 0.38 \\
Memorandum items: & \multicolumn{2}{c}{ (percent) } \\
Short-term assets/total assets & 33.32 & 40.26 \\
Short-term foreign currency assets/total short-term assets & $\ldots$ & 22.72 \\
\hline
\end{tabular}

Source: Bol, and staff estimates.

1/ Excluding Israeli treasury bills.

\section{INSURANCE STRESS TESTS}

\section{A. Introduction and background}

32. This section covers stress testing of the long term savings and insurance sector. This work was conducted with regard to the circumstances in place and the practices employed in November 2011.

33. The stress tests are largely based on the authorities' previous analysis, including a Quantitative Impact Study (QIS) 5 exercise. The assessors, together with the authorities, designed relevant shocks to assess possible vulnerabilities of the insurance and pension sectors. 


\section{The Israeli insurance sector}

34. The Israeli insurance market is well developed and sophisticated. With total premium income of US\$11.2 billion, the Israeli insurance market is currently the 32nd largest in the world. ${ }^{9}$ Total premiums were equal to 5.2 percent of GDP in 2010. This compares well with developed countries such as the United States at 8 percent and Spain at 5.4 percent and is far higher than any of the neighboring countries. Average premium per capita is also used as an indicator of insurance industry development. The figure for Israel for 2010 was US\$1,534, 28th highest in the world and comparing well with Spain at US\$1,650. There are 25 licensed insurers, 13 of which are active in the life insurance market.

\section{The life insurance sector has experienced strong growth over the past several} years, primarily as a result of legal changes which saw banks exit the long-term savings market. Having in mind the potential for tied selling of insurance products with other banking services, in 2005 the government adopted the recommendations of the Bachar Commission, essentially removing banks from the long term savings market. This led to rapid growth for life insurers as these institutions moved into the space vacated by the banks. For example, since 2008 life insurance industry assets have grown by a compound annual rate of 20.5 percent, from NIS 144.8 billion to NIS 210.2 billion.

\section{The insurance business is concentrated and this has implications for operational} risk. In 2009, five large, sophisticated insurers accounted for 90.4 percent of Israeli insurance premiums, which totaled NIS 42 billion. The life insurance companies participate directly and indirectly through holdings in pension funds and provident funds in the long term saving sector, currently accounting for over 60 percent of the market. The system has been designed to facilitate the mobility of funds and a maximum 15 percent market share limitation for acquisitions has been introduced for the pension fund sector. The emergence of these large institutions over a relatively short period of time, combined with an increasingly sophisticated supervisory regime, is giving rise to stresses on managerial and technological resources within the industry. It will be important for CMSID to be aware of these developments and to manage the supervisory process accordingly.

\section{Recent performance}

\section{The financial crisis of $\mathbf{2 0 0 8}$ hit Israel hard, including the insurance sector.}

However, the largest part of the life insurance industry involves the sale of unit-linked products, with the result that investment risk rests primarily with policyholders rather than the insurers. The long term savings products remain protected from early withdrawals by regulations thus protecting the liquidity of pension funds.

\footnotetext{
${ }^{9}$ Swiss Re Sigma No 2/2011, World Insurance in 2011.
} 
38. Available financial soundness indicators for insurers show recovery from the effects of the global crisis. The CMISD early warning system based on 47 financial ratios combined into 6 parameters that track insurers' stability shows recovery from the crisis. See Figure 5. During 2008 the key indicators, profitability and capital adequacy, dropped to the lowest level. At the second quarter of 2011 all indicators are back to the average level.

\section{The solvency threat for the insurance sector generated by the crisis appears to}

have been averted. Notwithstanding the liabilities structure of the insurance sector where over 60 percent of the life products transfer the investment risk to the policyholders, the 2008 reported average capital surplus level dropped to 8 percent and was just above the requirement in many cases. The recovery has been fast and effective; the CMISD capital increment plan that started in 2008 increased by around 40 percent and the capital requirements thus contributed significantly to the solvency of the system and the current capital surplus of 29 percent is in reference to this incremented new capital requirement. However, for a few participants the crisis appears not to be over and their capital surplus remains relatively low on the new basis.

Figure 5. Israel: Insurance Early Warning Indicators

Performance indicators of the CMISD early warning system

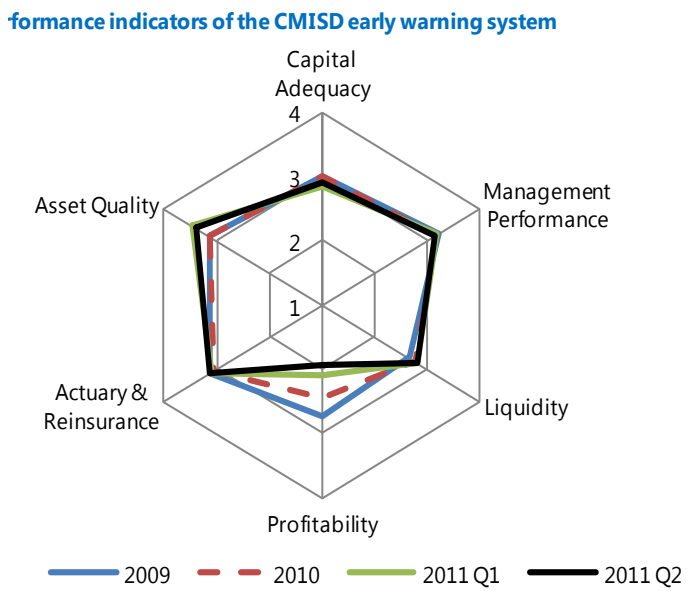

surce: CMISD
Insurers capital surplus from 2007 to 2010

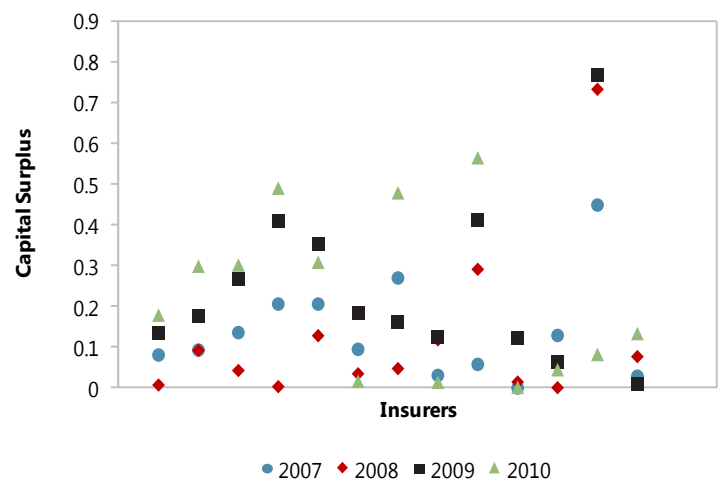

Source: CMISD

40. Market perception on the insurance sector has returned to pre-crisis levels. As a tool to assess market perception, the CMSID uses the Merton model to assess the distance to default of the traded Insurance Holding companies. While the distance-to-default parameter provides no direct indication of the solvency of the insurance companies under the Holding Companies due to other relevant aspects affecting the shares of the Holding Companies, such as leverage and also due to other factors influencing the underlying insurers' solvency (e.g., the underwriting risk possibly not captured by the market), nevertheless the market 
perception is an important indicator of the assessment of the market on the overall insurance business credit risk. As can be seen from Figure 6, below, the low levels of market appetite for the insurance business during the 2008 crisis have moved back to 2007 levels as of May 2011. The BOI and CMISD are carrying out an analysis of the insurance sector on linking macro factors to the insurance company risk indicators from MKMV (including a MKVM distance to distress indicator). This work is ongoing and not completed at the time of finalization of this ST technical note.

Figure 6. Israel: Insurers' Distance-to-Distress

(Selected Israeli insurance companies)

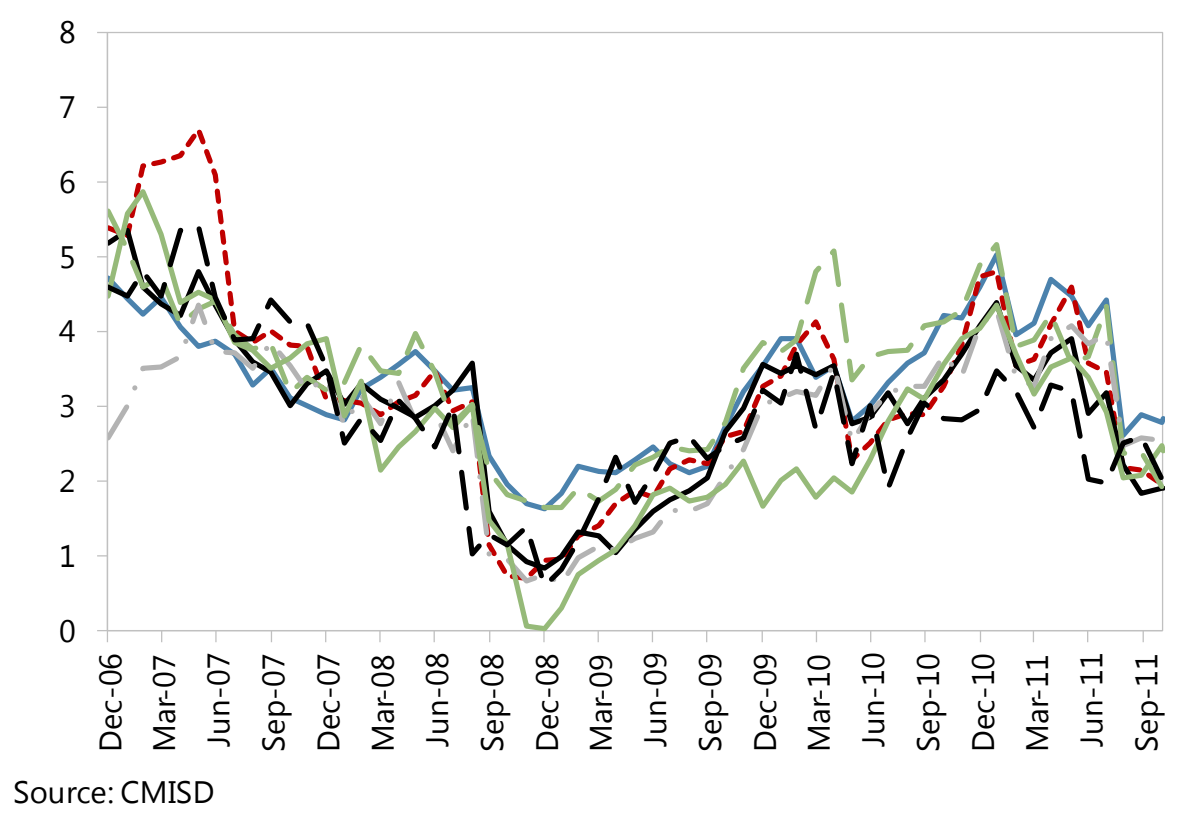

\section{Regulatory environment}

41. Investment regulation has been overhauled towards a principles-based approach and uniformity among different types of providers. New investment regulation issued in 2002 with recent amendments in 2009 and 2010 largely removed investment prescriptions that applied to pension funds, provident funds and life insurance long term saving products as well as unified the rules among the three types of providers. Under current regulation the limitations apply on concentration in single issuer, single issue, means of control, loan security, etc. The functions of investments committees are well defined including their composition, independence and experience of their members.

42. The CMISD supervisory regime has been importantly enhanced after the $\mathbf{2 0 0 8}$ crisis and now includes stress testing and an early warning system. In the area of stress testing, the CMISD runs a sensitivity analysis of the insurer's capital against market risks as well as the analyses of required stress testing carried out by the insurance companies. This surveillance work is complemented by the use of an early warning system based on the 
tracking of 6 indicators; market indicators like market value to book value and Merton's distant to default; spreads of deferred capital notes issued by the insurers and credit ratings.

43. The current already risk sensitive solvency framework will be enhanced with the introduction of a Solvency 2-type regime in 2013. In preparation for the introduction of Solvency 2 the CMISD has run a quantitative impact analysis similar to the EIOPA QIS5 exercise. The EIOPA directive has been used with adaptations and clarifications where relevant to the Israeli market conditions

\section{B. Stress Test Considerations}

\section{Stress testing approach}

44. The stress tests need to differentiate different types of liabilities depending on who bears the risk. Insurance companies in Israel manage two types of liabilities, those in which the investment risk of the assets held against them is borne by the insurer and those where the investment risk is passed to the policyholders. The latter has no impact on the solvency of the company and represents just over 50 percent of current assets, or NIS 132.5 billion.

- A stress test to evaluate the sensitivity to market shocks on the assets where the policyholders carry the investment risk. This stress test includes the assets of pension funds and provident funds since all three types of entities provide the same long term saving product for retirement.

- The second stress test applies to the capital and the insurer's own funds hold against liabilities where they bear the investment risk. In these stress test besides the market shocks insurance specific shock have been added.

45. A series of dedicated stress tests were carried out in close cooperation with the authorities. While the investment risk on over 60 percent of the life products is born by the policyholders, due to the social character of LTS products and the possible impact on households, evaluating the market risk on these products is relevant for stability purposes that a severe impact on the policyholder assets could cause. In this sense stress tests were run on both, the LTS portfolios of life insurers, pension funds, and provident fund excluding the guaranteed return government bonds that are deemed risk free. Further stress tests were conducted in particular to assess the sensitivity of the non life and pure risk life business. Here, the shocks not only include market risks, but also insurance risks impacting the claims ratio in different lines of business. In addition to the two top-down stress tests, the tests conducted by the insurance market under the supervision of CMISD (similar to the QIS-5 exercise led by the European Insurance and Occupational Pensions Authority-EIOPA) was analyzed, and the companies' own stress tests evaluated. 


\section{Results and Discussion}

46. The results of the shocks on the LTS products show resilient portfolios. Market shocks of similar magnitude as those occurring during the $4^{\text {th }}$ quarter of 2008 and a simulated scenario of a severe local shock ${ }^{10}$ would result in a 7.7 percent loss on the long term savings, individual portfolios, on average. It is evident from the top left panel of Figure 7, below, that only about 20 percent of the average LTS portfolio was comprised of equities, with the result that the LTS portfolios were significantly shielded from declines in the equity markets. These results appear to dismiss the possible activation of the current government guarantee issued during the crisis on the pensions close to retirement in the form of a stop loss after a 50 percent loss in value. The differences on the impact of the shocks range from 10 percent to 6 percent depending on the provider of the LTS. This difference will probably diminish as the harmonizing regulation recently enacted begins to affect operations.

\section{The main risk for the LTS appears to be shifted from market to operational and}

legal risks. The stress test results suggest a bearable loss of less than 10 percent under a severe shock similar to the $4^{\text {th }}$ quarter 2008 crisis. An important hedge to the shocks was the current well diversified portfolios that include a 20 percent foreign investment position. The main risk appears to be generated by the substantial flexibility and virtually unlimited mobility inherent to the pension products currently being offered on the market. Additional factors were the variety of collective agreements with respect to the management fees and service offerings. The regulatory risk of changing market and economic conditions, for future but also for existing contracts, adds complexity to the system. Simplifying the pension system should be considered as mitigation for the operational and legal risk and at the same time will have the effect of reducing costs.

\section{The stress test applied to the insurance business excluding the saving products}

did not expose unexpected vulnerabilities. The stress tests applied to the nonlife and pure risk life products appear to confirm that four of the top companies are sufficiently capitalized to withstand with ease 10 percent deterioration in their claims in their main lines of business in the midst of a $4^{\text {th }}$ quarter 2008 similar crisis. Market risk remains the major risk and some companies are positively impacted in their capital position by a deterioration of claims due to reserve release and tax credits. As can be seen from the bottom panel of Figure 8, none of the six companies showed a negative solvency position. However, two companies, already challenged to meet the new capital requirements, show substantial capital deficits in the tested scenarios.

\footnotetext{
${ }^{10}$ For details see the stress matrix and Appendix V.
} 
Figure 7. Israel: Long Term Savings (LTS) Stress Test Results

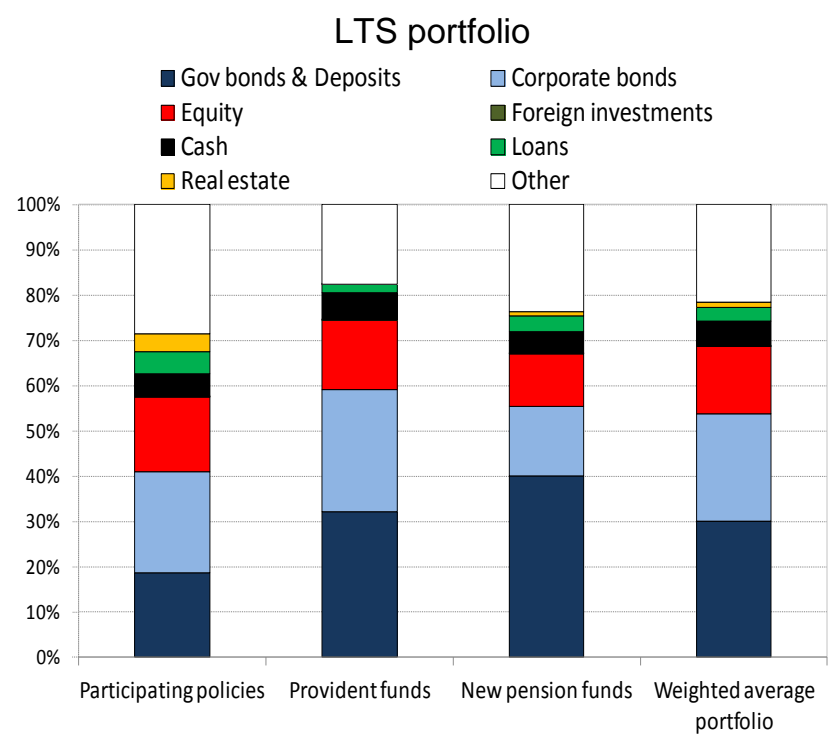

LTS in local and foreign investments (In percent)

\begin{tabular}{|c|cc|}
\hline & $\begin{array}{c}\text { Local } \\
\text { investments }\end{array}$ & $\begin{array}{c}\text { Foreign } \\
\text { investments }\end{array}$ \\
\hline $\begin{array}{c}\text { Participating } \\
\text { policies } \\
\text { Provident } \\
\text { funds }\end{array}$ & 79.4 & 20.6 \\
$\begin{array}{c}\text { New pension } \\
\text { funds } \\
\text { Weighted } \\
\text { average } \\
\text { portfolio }\end{array}$ & 88.2 & 11.8 \\
\hline
\end{tabular}




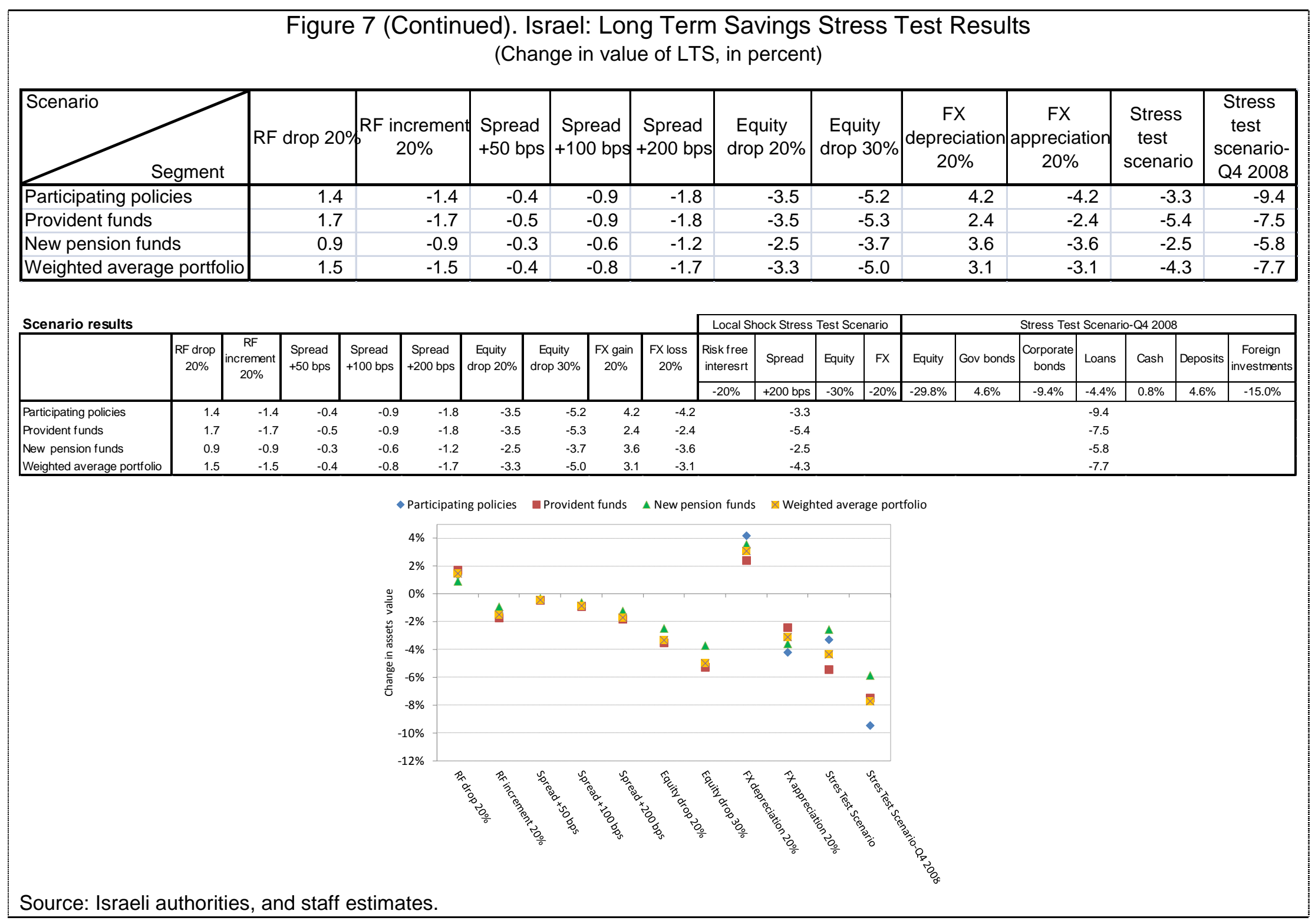


Figure 8. Israel: Insurance Own Funds Stress Test Results

Own funds portfolio

(Percentage shares as of June 2011)

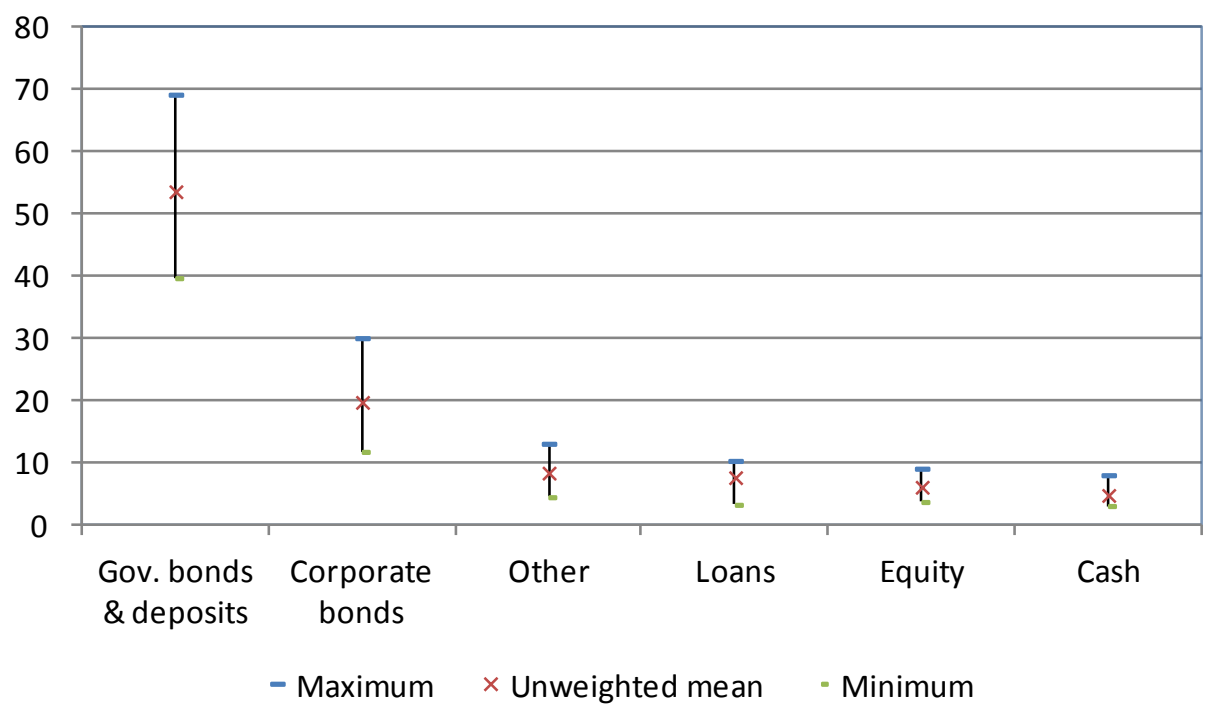

Change in insurers' capital surplus

(In percentage points)

\begin{tabular}{|c|c|c|c|c|c|c|c|c|c|c|c|c|}
\hline Scenario & Mortality & Motor & Property & $\begin{array}{c}\text { Mortality } \\
\text { +motor }\end{array}$ & $\begin{array}{l}\text { Mortality } \\
\text { +motor+ } \\
\text { property }\end{array}$ & $2008 Q 4$ & $\begin{array}{r}2008 Q 4+ \\
\text { mortality }\end{array}$ & $\begin{array}{c}\text { 2008Q4+ } \\
\text { motor }\end{array}$ & $\begin{array}{r}2008 \mathrm{Q} 4+ \\
\text { property }\end{array}$ & $\begin{array}{c}2008 Q 4+ \\
\text { motor+ } \\
\text { property }\end{array}$ & $\begin{array}{c}2008 Q 4+ \\
\text { mortality+ } \\
\text { motor }\end{array}$ & $\begin{array}{c}2008 Q 4+ \\
\text { mortality+ } \\
\text { motor+ } \\
\text { property }\end{array}$ \\
\hline$A$ & -0.9 & -0.3 & -0.4 & -1.2 & -1.6 & 1.5 & 0.6 & 1.2 & 1.2 & 0.9 & 0.3 & 0.0 \\
\hline B & -0.4 & -0.5 & -0.6 & -0.8 & -1.4 & -4.0 & -4.4 & -4.5 & -4.6 & -5.1 & -4.9 & -5.4 \\
\hline C & -0.6 & -0.4 & -0.6 & -1.1 & -1.6 & -10.9 & -11.5 & -11.3 & -11.5 & -11.9 & -11.9 & -12.5 \\
\hline D & -1.3 & -0.8 & -1.3 & -2.1 & -3.4 & -3.5 & -4.9 & -4.3 & -4.8 & -5.6 & -5.6 & -6.9 \\
\hline$E$ & -0.7 & -0.7 & -0.8 & -1.4 & -2.2 & -2.8 & -3.5 & -3.4 & -3.5 & -4.2 & -4.2 & -5.0 \\
\hline $\mathrm{F}$ & -0.2 & -1.5 & -1.8 & -1.7 & -3.5 & -9.6 & -9.7 & -11.1 & -11.4 & -12.9 & -11.3 & -13.1 \\
\hline
\end{tabular}

Source: Israeli authorities, and staff estimates.

49. The variability on the results of the adapted QIS 5 exercise indicated the need for additional work in preparation for Solvency 2. The QIS 5 exercise was carried out by the whole market within 2 months. The CMISD provided a series of adaptations on the EIOPA QIS 5 parameters that appear to be straight forward, like the definition of risk free interest discount curve, the treatment of government bonds and of local equities. However, some parameters need further study, such as lapses, tax deferrals, treatment of EPIFP, and appropriate correlation matrices for composite companies. The insurance risks also appear to required further calibration. The results showed a small decease in the asset value, confirming the current practice of market consistence asset valuation. The resulting liabilities experienced a reduction showing some conservatism in the current existing solvency regime. However, here the assumptions on the liquidity premium, lapses and extrapolation of the risk free interest curve could have played an important role. The results on the SCR exhibit large charges for equity, interest, lapse and 
morbidity risks, suggesting the need for a proper calibration of these charges before an acceptable level of confidence is assigned to the results.

\section{The supervisory stress tests run by the companies for internal risk analysis need to}

be more stringent. The stress tests run by the companies at the requirement of the authorities are a combination of historical events and single shocks. The 2002 and 2008 crises are selected scenarios. These historical scenarios are complemented with a series of market shocks on equity, spreads, yield curves, sovereign risk and a combination of them. The results show single digit losses in the technical provisions and in extreme cases impact on capital in the order of 25 percent. The important value of the stress testing in uncovering hidden vulnerabilities cannot be achieved if the insurance and the market risks are not combined together in a stress scenario. The value of current stress testing practice would increase if to the historical scenarios an insurance shock is added, like an earthquake during a 2002 crisis scenario. Also the use of reverse stress tests should be introduced as a tool to better understand the real vulnerabilities of the system. A normalized industry wide stress test should be designed based on the input and information received from the companies' own stress testing. This would allow comparison of the solvency of the companies as well as detection of possible systemic risks.

\section{INTEgRATED SYSTEMIC RISK STRESS TESTING}

\section{Stress testing analyses for banks, insurance companies and other sectors could be} more closely integrated to help improve systemic risk analysis. The CMISD needs to work more closely with the BOI on insurance stress testing (e.g., on improving satellite models to include macro-financial variables and devising consistent scenarios). Stress testing of systemic risk should be developed to capture systemic risk dependence between institutions (e.g., through the systemic CCA).

\section{Stress testing activities should be designed to guide micro- and macroprudential} policy to enhance financial stability. Integrated stress testing analysis should be expanded to analyze macroprudential policies including household credit risk, contingent liability risks, risk transfer between sectors (e.g., corporate, insurance companies, groups, and other sectors). Stress testing can also help analyze the potential benefits (i.e., reduced vulnerability from lower default risk and implied credit spreads), of possible new microprudential and macroprudential measures. This is consistent with the recommendations on macroprudential supervision and policy analysis. The special macroprudential unit which has been set up can benefit from integrated systemic risk stress testing to analyze implications of macroprudential policies. 


\section{APPENDix I. Stress TeSt MATRIX FOR BANKING: SOLVENCY RiSK}

\begin{tabular}{|c|c|c|}
\hline \multirow[t]{2}{*}{ Domain } & \multicolumn{2}{|c|}{ Assumptions } \\
\hline & $\begin{array}{c}\text { Top-Down Balance Sheet ST by } \\
\text { Authorities }\end{array}$ & $\begin{array}{c}\text { Top-down Contingent Claims Analysis ST by } \\
\text { Authorities and FSAP Team }\end{array}$ \\
\hline Institutions included & - 5 largest institutions & - 5 largest institutions \\
\hline Market share & $\begin{array}{l}\text { - } 93 \text { percent of assets } \\
\text { - } 95 \text { percent of total sector lending }\end{array}$ & $\begin{array}{l}\text { - } 93 \text { percent of assets } \\
\text { - } 95 \text { of total sector lending }\end{array}$ \\
\hline $\begin{array}{l}\text { Data and baseline } \\
\text { date }\end{array}$ & $\begin{array}{l}\text { - Supervisory data } \\
\text { - End-June } 2011 \\
\text { - Consolidated banking group }\end{array}$ & $\begin{array}{l}\text { - Balance sheet data (public) plus market } \\
\text { data (MKMV inputs) } \\
\text { - End-June } 2011 \\
\text { - Banks have quoted market capitalization }\end{array}$ \\
\hline Methodology & $\begin{array}{l}\text { - Banking Supervision Department's } \\
\text { models: profit models (net interest } \\
\text { income, operating and other income, } \\
\text { operating and other expenses), } \\
\text { corporate sector losses, housing credit } \\
\text { losses, households' non-housing credit } \\
\text { losses and government debt solvency } \\
\text { models }\end{array}$ & $\begin{array}{l}\text { - Macro-econometric factor model combined } \\
\text { with MKMV data on expected default } \\
\text { frequency (EDFs) and market value of } \\
\text { bank assets }\end{array}$ \\
\hline Stress test horizon & - End-June 2011 to end 2014 & - End-June 2011 to end 2014 \\
\hline Shocks & \multicolumn{2}{|c|}{$\begin{array}{l}\text { Scenario analysis } \\
\text { - Base, Adverse } 1 \text { (domestic shock), Adverse } 2 \text { (serious international shock) } \\
\text { - Macro scenarios are shocks conditioned upon GDP, inflation, interest rates, exchange } \\
\text { rate, unemployment, short and long-term interest rates, equity prices, bond prices } \\
\text { (AA, A, BBB, unrated, and real estate bond spreads) } \\
\text { - Adverse } 1 \text { is } 1.9 \text { percent GDP decline and Adverse } 2 \text { is } 5.9 \text { percent decline from Base } \\
\text { scenario GDP growth of } 3.1 \text { percent in } 2012 \text { (see Table } 1 \text { ) } \\
\text { Sensitivity analysis applied in the balance sheet ST } \\
\text { - Single-factor shocks in balance sheet stress testing: } \\
\text { - Credit shock to largest corporate group and largest three borrowers } \\
\text { - } 25 \text { percent decline in stock market value } \\
\text { - } 15 \text { percent change in exchange rate } \\
\text { - } 200 \text { basis point change in interest rates } \\
\text { - Vulnerable European government debt shock: } 30 \text { and } 10 \text { percent write off }\end{array}$} \\
\hline $\begin{array}{l}\text { Risks/factors } \\
\text { assessed }\end{array}$ & $\begin{array}{l}\text { - Credit losses, profitability, fixed income } \\
\text { holdings of banks/sovereigns, } \\
\text { exchange rate, dividends, and taxes }\end{array}$ & $\begin{array}{l}\text { - Changes in market value of assets, EDFs, } \\
\text { expected losses to creditors, implied credit } \\
\text { spread and CCA capital ratio }\end{array}$ \\
\hline $\begin{array}{l}\text { Calibration of risk } \\
\text { parameters }\end{array}$ & $\begin{array}{l}\text { - Loan Loss Provisions and quasi-PDs } \\
\text { linked to satellite model of macro } \\
\text { factors-for housing credit, household } \\
\text { non-housing credit, corporate credit } \\
\text { (using PDs and LGDs), market risk } \\
\text { estimates government debt and foreign } \\
\text { financial institution bond holdings }\end{array}$ & $\begin{array}{l}\text { - EDF and market value of asset projections } \\
\text { based on historical macro-econometric } \\
\text { relationships. EDF projections for the three } \\
\text { scenarios used to calculate additional risk } \\
\text { indicators (expected losses and credit } \\
\text { spreads, using market price of risk } \\
\text { parameters, as well as market } \\
\text { capitalization and CCA capital ratios) }\end{array}$ \\
\hline $\begin{array}{l}\text { Behavioral } \\
\text { adjustments } \\
\text { (e.g., nature of } \\
\text { balance sheet } \\
\text { growth, zero profit, }\end{array}$ & $\begin{array}{l}\text { - Constant balance sheet } \\
\text { - If ROE }>6 \text { percent and CT1 between } 8 \\
\text { to } 8.5 \text { percent then dividends are } 35 \\
\text { percent; if ROE is }>6 \text { percent and CT1 } \\
\text { is }>8.5 \text { percent dividends are } 50\end{array}$ & $\begin{array}{l}\text { - Constant CCA balance sheet (i.e., } \\
\text { constant debt default point) }\end{array}$ \\
\hline
\end{tabular}




\begin{tabular}{|c|c|c|}
\hline \multirow[t]{2}{*}{ Domain } & \multicolumn{2}{|c|}{ Assumptions } \\
\hline & $\begin{array}{c}\text { Top-Down Balance Sheet ST by } \\
\text { Authorities }\end{array}$ & $\begin{array}{c}\text { Top-down Contingent Claims Analysis ST by } \\
\text { Authorities and FSAP Team }\end{array}$ \\
\hline $\begin{array}{l}\text { dividend payout, } \\
\text { asset disposal, } \\
\text { lending standards, } \\
\text { portfolio allocation) }\end{array}$ & $\begin{array}{l}\text { percent; if } \mathrm{ROE}<6 \text { percent dividends. } \\
\text { are } 0 \\
\text { - RWAs changed according to } \\
\text { standardized approach rules (only } \\
\text { exchange rate affects RWA) }\end{array}$ & \\
\hline $\begin{array}{l}\text { Regulatory } \\
\text { standards and } \\
\text { hurdle rates }\end{array}$ & $\begin{array}{l}\text { - Hurdle rates: } \\
\text { - Total Capital hurdle rate is } 9 \text { percent } \\
\text { CAR - local regulatory requirements } \\
\text { - Core Tier } 1 \text { threshold of } 5 \text { percent }\end{array}$ & $\begin{array}{l}\text { - Comparison of CCA capital ratio under } \\
\text { scenarios to } 2008 / 2008 \text { crisis } \\
\text { - Number of banks that have credit risk } \\
\text { indicators above various thresholds }\end{array}$ \\
\hline Results & $\begin{array}{l}\text { Scenario analysis } \\
\text { - CAR for all banks is above } 9 \text { percent } \\
\text { hurdle rate } \\
\text { - CT1 for all banks is above } 5 \text { percent } \\
\text { threshold rate } \\
\text { - One bank has CT1 of } 6.9 \text { percent } \\
\text { under Adv } 2 \text { scenario in } 2012 \\
\text { Sensitivity analysis - Single Factor } \\
\text { (smallest to largest impact as percent } \\
\text { CT1) } \\
\text { - Credit shock largest borrower group } \\
\text { Impact is } 8.5 \text { to } 12.6 \text { percent of CT1 } \\
\text { - Credit shock largest three borrowers } \\
\text { Impact is } 4.3 \text { to } 6.6 \text { percent of CT1 } \\
\text { - Stock market decline of } 25 \text { percent } \\
\text { Impact is } 0.3 \text { to } 3.8 \text { percent of CT1 } \\
\text { - Exchange rate depreciation of } 15 \\
\text { percent Impact is } 0.2 \text { to } 3.1 \text { percent of } \\
\text { CT1 } \\
\text { - Interest rate increase } \\
\text { Impact is -5.0 to } 5.0 \text { percent of CT1 } \\
\text { Interest rate decrease } \\
\text { Impact - } 4.8 \text { to } 4.7 \text { percent of CT1 } \\
\text { - European peripheral exposures } \\
\text { Impact is } 0.4 \text { to } 1.4 \text { percent of CT1 }\end{array}$ & $\begin{array}{l}\text { Scenario analysis } \\
\text { - CCA capital ratios, expected losses and } \\
\text { implied spreads are higher than 2008/2009 } \\
\text { crisis under Adverse } 2 \\
\text { - If a threshold of } 300 \text { bps for the implied } \\
\text { credit spread is used, spreads for two } \\
\text { banks go above or are very close to this } \\
\text { threshold in } 2012\end{array}$ \\
\hline
\end{tabular}




\section{ApPendix II. SATEllite Models ANd Assumptions for Balance Sheet Stress Testing}

Profits - based on three satellite models:

\begin{tabular}{|l|l|}
\hline Model & Explanatory Variables \\
\hline NII - Net Interest Income & CI Changes in the composite Index ${ }^{11}$ \\
IR $\quad$ BOI interest rate \\
\hline $\begin{array}{l}\text { OI - Operating Income and Other } \\
\text { Income }\end{array}$ & CI Changes in the composite index \\
\hline OE - Operating and Other Expenses & CI Changes in the composite index \\
\hline
\end{tabular}

The depended variable in these 3 OLS models is the ratio of the profit components to total assets.

$$
\begin{aligned}
& N I I_{t}=\alpha_{1}+\alpha_{2} * \Delta C I_{t-1}+\alpha_{3} * I R_{t}+\alpha_{4} * D \\
& O I_{t}=\beta_{1}+\beta_{2} * \Delta C I_{t-1}+\beta_{2} * O I_{t-1} \\
& O E_{t}=\delta_{1}+\delta_{2} * \Delta C I_{t-1}+\delta_{3} * O E_{t-1}
\end{aligned}
$$

D is 2008 crisis dummy. The model includes additional explanatory variables such as the spread between government bonds, BOI interest rate and GDP growth but they were not statistically significant.

The models were estimated based on the aggregate results of the five major banks since there is a great variation of profitability between the banks. In order to fit the model to each individual bank, an adjustment is used based on the average rate of profitability (profit to total assets) of each single bank between 2009 to June 2011. The sample we used: 1997Q1-2010Q4.

\section{Housing credit losses}

A linear regression was used to estimate housing credit losses. Household credit risk is estimated by the ratio of loan-loss provision in housing to housing credit, and the macro factors included in the model are unemployment rate (U) and $\mathrm{BOI}$ interest rate (IR):

$L L P^{\text {housing }}$ is the loan loss provision to credit for the housing segment.

$L L P^{\text {housing }}{ }_{t}=\gamma_{1} * I R+\gamma_{2} * U_{t-1}+\gamma_{3} * D+\gamma_{4} * \operatorname{LOSS}^{\text {housing }}{ }_{t-1}$

\footnotetext{
${ }^{11}$ Changes in the Composite Index are not included in the set of the macroeconomic variables. We used GDP growth as an estimate to changes in the Composite Index. There is high correlation between the two variables.
} 
D is 2006 Q1 dummy which was included due to an on-site examination conducted on the whole banking system. The sample we used: 2002Q1-2010Q4.

It's important to emphasize that the historical losses are very low, even though this period includes two major crises $(2002,2008)$.

\section{Appendix Figure 9 . Israel: Housing Credit LLP to Credit \\ (In percent)}

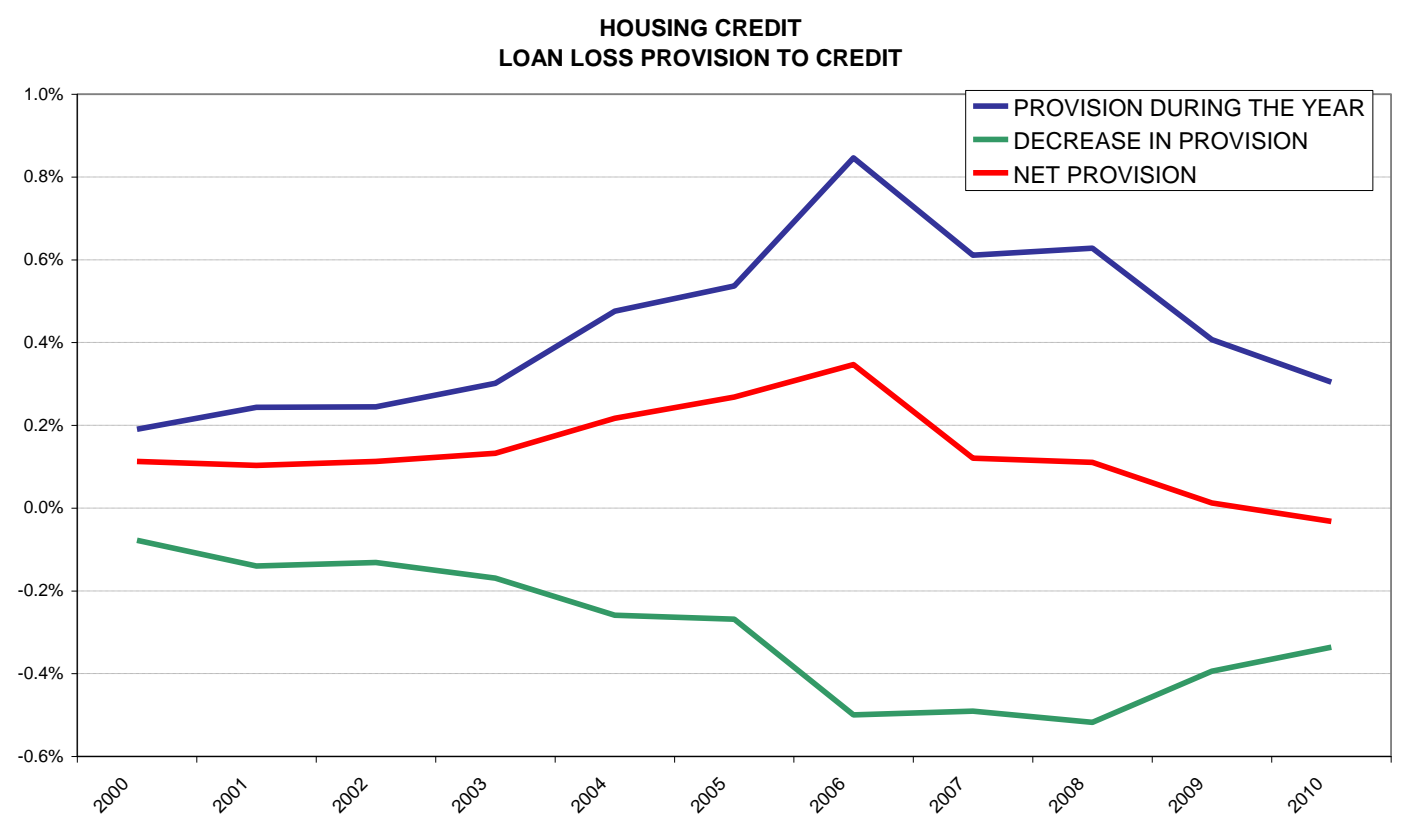

\section{Households other credit losses}

A linear regression was used to estimate housing credit losses. Household credit risk is estimated by the ratio of loan-loss provision of households-other to other credit $\left(L L P^{\text {households }}\right)$, and the macro factors included in the model are the unemployment rate and the public's portfolio of financial assets.

Two macroeconomic factors were found to have a significant effect on credit risk:

- changes (in percentage points) in the unemployment rate $(U)$.

- changes (in percent) in the financial portfolio balance of the public (ASSETS $)^{12}$.

\footnotetext{
12 The financial portfolio of the public is not included in the set of the macroeconomic variables. There is a high correlation between the changes in the financial portfolio of the public and changes in Tel-Aviv 100 index (0.86). An OLS regression was used to estimate the changes in the financial portfolio using the explanatory variable - changes in Tel-Aviv 100 index.
} 


$$
\operatorname{LLP}_{t}^{\text {households }}=\eta_{1}+\eta_{2} * \Delta U_{t-1}+\eta_{3} * \Delta \text { ASSETS }_{t-1}
$$

The sample we used: 2002Q1-2010Q4

\section{Corporate (Business Sector) losses}

The impact of macroeconomic factors on the quality of the bank's credit portfolio was analyzed, based on the model of Wilson (1997) with some adjustments.

In the first stage, the default rate is modeled using a logistic function: ${ }^{13}$

$$
P D_{t}=\frac{1}{1+e^{-y_{t}}}
$$

where:

$P D_{t}$ is the quasi-probability of default (probability of provision) at time $t$ which is obtained by dividing the number of firms that has made a loan-loss provision by the number of active firms during that period.

$y_{t}$ is given by the logit transformation: ${ }^{14}$

$$
L\left(P_{t}\right)=\ln \left(\frac{P D_{t}}{1-P D_{t}}\right)=y_{t}
$$

The logit transformation of the default rates is estimated using a number of macroeconomic variables.

1) Changes in the Composite Index $(\mathrm{CI}):^{15}$

2) real interest rate (R_IR). ${ }^{16}$

3) changes in the Tel Aviv 100 Index (TA100).

$$
y_{t}=v_{1}+v_{2} * \Delta C I_{t-1}+v_{2} * R_{-} I R_{t}+v_{3} * \Delta T A 100_{t}+v_{4} * A R(1)+\varepsilon_{t}
$$

\footnotetext{
${ }^{13}$ In bankruptcy models, the logit function is commonly used in order to ensure that the rate of default falls within the range $[0,1]$.

${ }^{14}$ While the value of $P D_{j, t}$ ranges from 0 to 1 , the value of $y_{j, t}$ ranges from $(-\infty)$ to $(+\infty)$.

${ }^{15}$ Changes in the Composite Index are not included in the set of the macroeconomic variables. We used GDP growth as an estimate to changes in the Composite Index. There is high correlation between the 2 variables.

${ }^{16}$ The real interest rate is calculated as $\left[\left(1+i_{t}\right) /\left(1+\pi_{t}\right)-1\right]$ where $i$ is the Bank of Israel interest rate and $\pi$ is the rate of inflation based on the CPI. It should be mentioned that the real interest rate was first calculated using expectations of inflation but this variable was found not to be significant.
} 
$\varepsilon_{i}$ is a vector of errors assumed to be independent and normally distributed.

In the final stage, a simulation of the future default rates is performed using the estimated parameters, errors and equations. A Monte Carlo simulation was used to determine the loss distribution of the corporate credit portfolio for various stress events. The sample we used was 1997Q1-2010Q4. ${ }^{17}$

Losses of the business sector in Scenario 1 and Scenario 2 were based on 99th percentile of the quasi PD distribution, although the probability of occurrence of these scenarios is very low. In our view, the $99^{\text {th }}$ percentile reflects various effects that are not captured by the macroeconomic model.

Appendix Figure 10 Israel: Quarterly Changes in the Composite Index and GDP

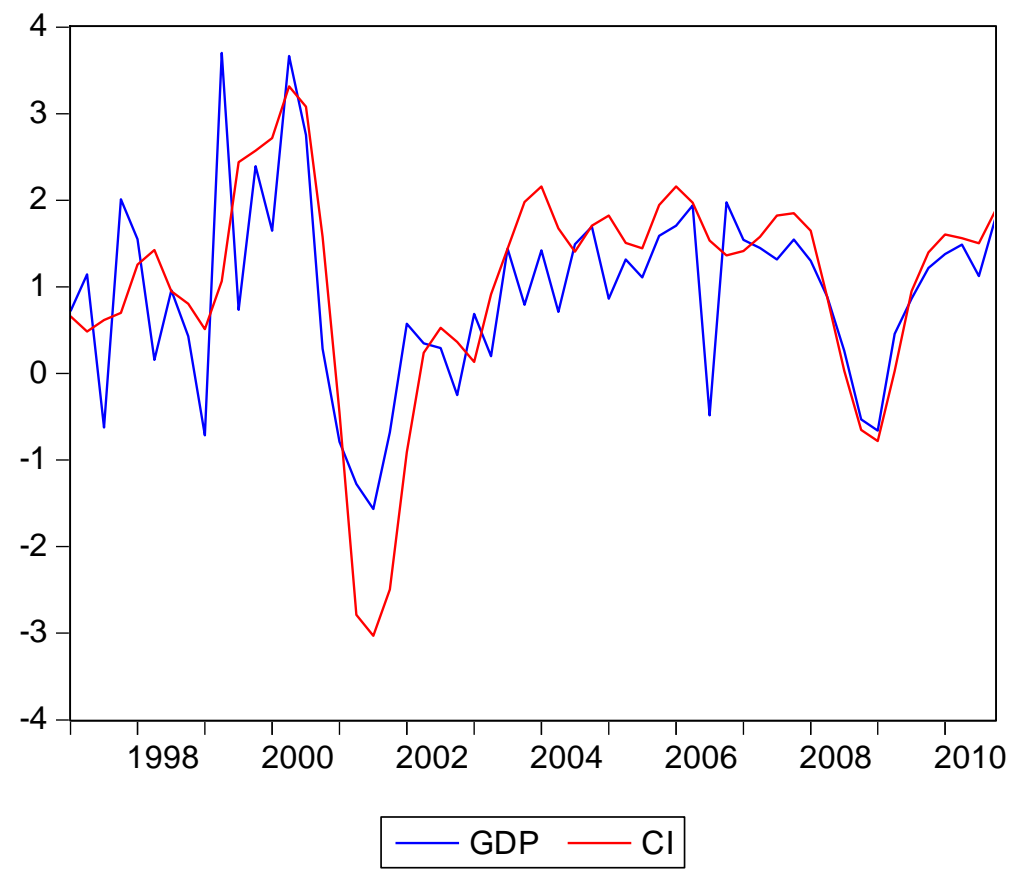

\section{Sovereign and Foreign Financial Institution Haircuts}

For Adverse Scenario 1, the BOI took the historical spreads observed at the 2001 recession, and assumed a convergence of the long term yield towards the above mentioned average rate in the last 6 quarters of the scenario. For Adverse Scenario 2, the historical spreads observed at the 2008 crisis were used, extending the highest long interest rate for a year (2012). Since in this scenario the economy doesn't recover and the recession is long, the spread is going down slowly and in the last 5 quarters is set to be the same and at a level that was observed at 2009Q4, after

\footnotetext{
${ }^{17}$ BOI Report on Credit Exposure.
} 
the crisis's peak and in the first stages of recovery, when BOI interest rate was still at a very low level. After obtaining the projected spreads, the spreads were added to the BOI interest rates to get the long term yield.

The haircut for the Israeli sovereign bonds was calculated by multiplying the quarterly changes in these yields by the average duration (which is about 2 year). Haircuts on financial institutions are based on the FINRA/Bloomberg Investment Grade U.S. Corporate Bond Yield Index. RD took the gap between the index and 5YR US bond yield. Since base and scenario 1 doesn't include any global crisis, no increase in yields and haircuts for financial institutions bonds was assumed. In scenario 2 the path is based on a rising yield towards the level observed in 2008Q4 and 2009Q1 and then trending to the level observed in 2011Q3. The haircut for the financial institution was calculated by multiplying the quarterly changes in these yields by the average duration (2 year).

\section{Supervisory Model for Liquidity Risk Assessment - Asset/ liabilities with a maturity of up to one month ratio ${ }^{18}$}

This ratio is a product of dividing the liquid assets by liquid liabilities, as defined below:

Assets = Cash and deposits with the Bank of Israel minus the liquidity requirement, plus deposits with the Treasury plus deposits in banks minus intergroup bank deposits plus 94 percent of the total cash flow from Israeli government bonds and Bank of Israel instruments ("Makam") minus the total cash flow of pledged assets in favor of the clearing house and stock exchange plus 80 percent of the total cash flow of foreign sovereign bonds graded AA- and higher plus a 50 percent factor for foreign sovereign bonds graded BBB- up to AA-, plus 50 percent of the total cash flow of other corporate bonds graded A- and higher plus borrowed or purchased securities in Repo agreements plus mortgage loans plus 80 percent of other loans plus loans to the Israeli government plus 95 percent of assets from derivative instruments after applying all conversion factors plus 85 percent of other assets.

Liabilities $=$ Deposits from the Bank of Israel plus deposits from banks minus intergroup bank deposits plus 20 percent of the gap between deposits from the public and large deposits plus 50 percent of large deposits plus Israeli government deposits plus securities borrowed or purchased in a Repo agreement plus bonds and subordinate debenture instruments plus liabilities from derivative instruments plus liabilities plus 10 percent of all off-balance sheet items after applying all conversions factors. (Source of data: BOI Liquidity risk system in the ZPTM application, Charts 1-4.)

\footnotetext{
${ }^{18}$ The definition of liquid assets and liabilities specified below refers to all asset and liability items with a maturity of up to one month.
} 


\section{Adjusted standard model: ${ }^{19}$ Liquid asset/ total liabilities with a maturity of up to one month}

The ratio between assets and liabilities is as defined below:

Assets = Cash and deposits with the Bank of Israel minus the liquidity requirement plus deposits with the treasury plus deposits in banks minus intergroup bank deposits plus 94 percent of the total cash flow from Israeli government bonds and Bank of Israel instruments ("Makam') minus the total cash flow from pledged assets in favor of the clearing house and stock exchange.

Liabilities $=$ Total liabilities with a maturity of up to one month. ${ }^{20}$

\footnotetext{
${ }^{19}$ The definition of liquid assets in BOI "Proper Conduct of Banking Business" directives No. 342 is of a conservative nature. Therefore we are adjusting this definition as follows: We allow the recognizing of 94 percent of Israeli government bonds held, a similar method to the haircut applied by the Capital Markets Division of the BOI on these instruments when used as collateral for a monetary loan.

${ }^{20}$ The definition of liquid assets and liabilities specified below refers to all asset and liability items with a maturity of up to one month.
} 


\section{ApPendix III. Contingent Claims Analysis (CCA)}

\section{Contingent claims analysis is a generalization of the option pricing theory pioneered by} Black-Scholes (1973) and Merton (1973). Since 1973, option pricing methodology has been applied to a wide variety of contingent claims. Contingent claims analysis is used to construct risk-adjusted balance sheets and is based on three principles: (i) the values of liabilities (equity and debt) are derived from assets; (ii) liabilities have different priority (i.e., senior and junior claims); and, (iii) assets follow a stochastic process. Assets (present value of income flows, proceeds from assets sales, etc.) are stochastic and over a horizon period may be above or below promised payments on debt which constitute a default barrier. Uncertain changes in future asset value, relative to the default barrier, are the driver of default risk which occurs when assets decline below the barrier. We first discuss the dynamics of default risk, initially without the CCA framework but then with the CCA model.

The CCA model assumes that the total market value of assets, $A$, at any time, $t$, is equal to the sum of its equity market value, $E$, and its risky debt, $D$. Asset value is stochastic and may fall below the present value of promised payments on debt, which constitute a default barrier, $B .^{21}$ The value of risky debt is equal to default-free debt minus the present value of expected loss to creditors due to default. Default occurs when $A<B$. Equity value is the value of an implicit call option on the assets, with an exercise price equal to default barrier. The expected loss to bank creditors can be calculated as the value of an implicit put option, $P$, on the assets with an exercise price equal to $B$. The equity value, $E$, can be computed as the value of a call option:

$$
\begin{gathered}
E(t)=A(t) N\left(d_{1}\right)-B e^{-r T} N\left(d_{2}\right) \\
d_{1}=\frac{\ln \left(\frac{A}{B}\right)+\left(r+\frac{\sigma^{2}}{2}\right) T}{\sigma \sqrt{T}} \text { and } d_{2}=\frac{\ln \left(\frac{A}{B}\right)+\left(r-\frac{\sigma^{2}}{2}\right) T}{\sigma \sqrt{T}}
\end{gathered}
$$

where $r$ is the risk-free rate, $\sigma$ is the asset return volatility, and $N(d)$ is the cumulative probability of the standard normal density function below $d$. In its basic concept, the model assumes that the implicit options are of the European variety, and set the time until expiry,

$T$ equal to the time horizon of interest, usually between one and five years.

The formula for the implicit put option is:

$$
P_{E}(t)=B e^{-r T} N\left(-d_{2}\right)-A(t) N\left(-d_{1}\right)
$$

\footnotetext{
${ }^{21}$ MKMV defines this barrier equal to total short-term debt plus one-half of long-term debt based on empirical studies.
} 
Several widely-used techniques have been developed to calibrate the CCA models using a combination of balance sheet information and forward-looking information from equity markets. The market value of assets of corporations and financial institutions cannot be observed directly but can be implied using financial asset prices. From the observed prices and volatilities of market-traded securities, one can estimate the implied values and volatilities of the underlying assets in financial institutions. In the traditional Merton (1974) model, the calibration requires knowledge about value of equity, E, the volatility of equity, $\sigma_{E}$, and the distress barrier as inputs into equations $E=A_{0} N\left(d_{1}\right)-B e^{-r T} N\left(d_{2}\right)$ and $E \sigma_{E}=A \sigma_{A} N\left(d_{1}\right)$ in order to calculate the two unknowns, the implied asset value $\mathrm{A}$ and implied asset volatility $\sigma_{A} .22$

Once the asset value and asset volatility are known expected losses to bank creditors can be calculated. Asset value and asset volatility, together with the default barrier, time horizon, and the discount rate $\mathrm{r}$, are used to calculate the values of the implicit put option, $P_{E}$, which is the expected loss to bank creditors. The expected loss to bank creditors (the implicit put option $P_{E}$ ) formula can be broken down into its key components. The formula for the implicit put option can be rearranged and decomposed into the (i) risk-neutral default probability (RNDP), (ii) loss given default (LGD), and (iii) the value of the default-free value of debt (B).

$$
P_{E}=N({ }_{R N D P}\left(d_{2}\right) \underbrace{\left(1-\frac{N\left(-d_{1}\right)}{N\left(-d_{2}\right)} \frac{A}{B e^{-r T}}\right)}_{L G D} B e^{-r T},
$$

We can use the equations above to see that the spread can also be written as a function of the risk-neutral default probability (RNDP) and LGD, i.e.,

$$
s=-\frac{1}{T} \ln (1-R N D P \times L G D)
$$

The yield to maturity on the risky debt, $\mathrm{y}$, is defined by: $D=B e^{-y T}$

The credit spread is defined as $s=y-r,(r$ is the risk-free rate of interest $)$, thus

$$
\frac{D}{B}=e^{-y T}=e^{-s T} e^{-r T}, \text { and thus } e^{-s T}=\frac{D}{B e^{-r T}}=\frac{B e^{-r T}-P_{E}}{B e^{-r T}}=1-\frac{P_{E}}{B e^{-r T}}
$$

so the credit spread $s=-\frac{1}{T}\left(1-\frac{P_{E}}{B e^{-r T}}\right)$

\footnotetext{
${ }^{22}$ See Merton (1974, 1977, 1992), Gray, Merton, and Bodie (2008), as well as Gray and Malone (2008).
} 


\section{Modeling Default Risk}

Let us start with the evolution of bank assets over time horizon $t$ relative to the promised payments on the debt (default free value of the debt and deposits). The value of assets at time $\mathrm{t}$ is $A(t)$. The asset return process is $d A / A=\mu_{A} d t+\sigma_{A} \varepsilon \sqrt{t}$, where $\mu_{A}$ is the drift rate or asset return, $\sigma_{A}$ is equal to the standard deviation of the asset return, and $\varepsilon$ is normally distributed, with zero mean and unit variance. The probability distribution at time $T$ is shown in Appendix Figure 11(a) below.

\section{Appendix Figure 11a. Israel: Modeling Default Risk}

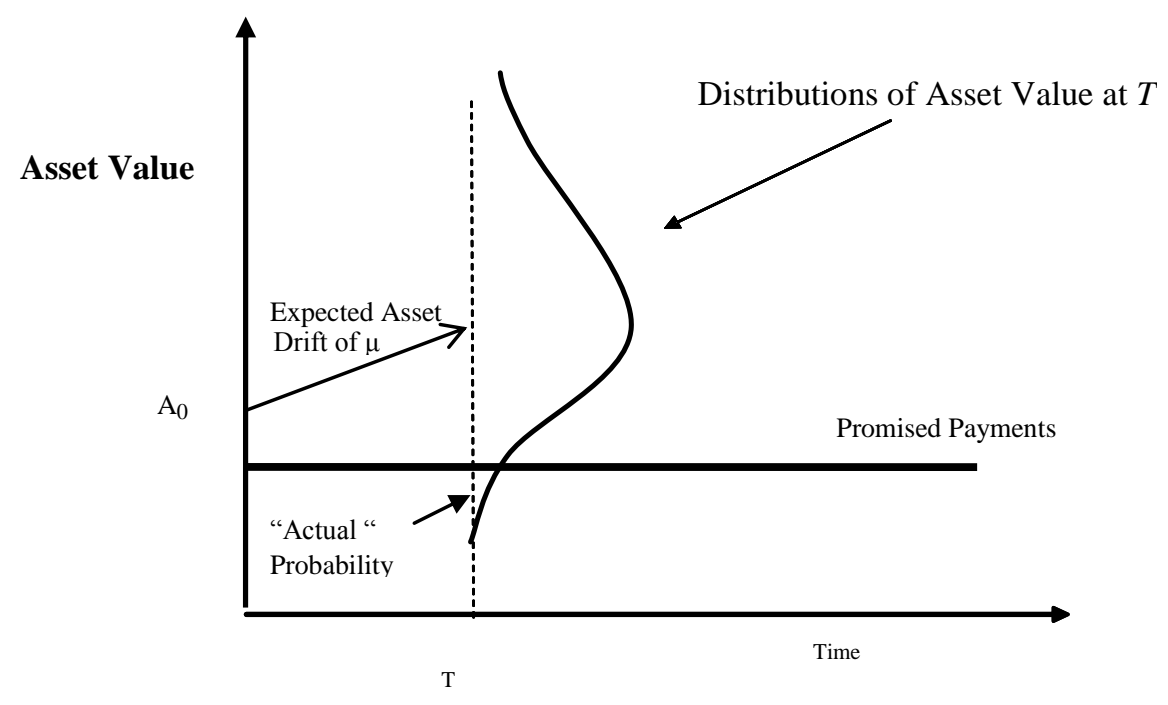

Default occurs when assets fall to or below the promised payments, $B_{t}$. The probability of default is $A_{t} \leq B_{t}$ so that

$$
\operatorname{Pr}\left(A_{t} \leq B_{t}\right)=\operatorname{Pr}\left(A_{0} \exp \left[\left(\mu_{A}-\sigma_{A}^{2} / 2\right) t+\sigma_{A} \varepsilon \sqrt{t}\right] \leq B_{t}\right)=\operatorname{Pr}\left(\varepsilon \leq-d_{2, \mu}\right) .
$$

Since $\varepsilon \square N(0,1)$, the "actual" probability of default is $N\left(-d_{2, \mu}\right)$, where $d_{2, \mu}=\left[\ln \left(A_{0} / B_{t}\right)+\left(\mu_{A}-\sigma_{A}^{2} / 2\right) t\right]\left(\sigma_{A} \sqrt{t}\right)^{-1}$. The "actual" probability of default is the area below the line (promised payment, i.e., the default barrier).

\section{Shown in Appendix Figure 11(b) below is the probability distribution (dashed line) with} drift of the risk-free interest rate, $\boldsymbol{r}$. The risk adjusted probability of default is $N\left(-d_{2}\right)$. The area below the distribution in Appendix Figure 11(a) is the "actual" probability of default. The assetreturn probability distribution used to value contingent claims is not the "actual" one but the "risk-neutral" probability distribution, which is the dashed line in Appendix Figure 11(b) with expected rate of return $r$, the risk-free rate. Thus, the "risk-neutral" probability of default is larger 
than the actual probability of default for all assets which have an actual expected return $(\mu)$ greater than the risk-free rate $r$ (that is, a positive risk premium). ${ }^{23}$

\section{Appendix Figure 11b. Israel: Actual vs. Risk Neutral Default Probabilities}

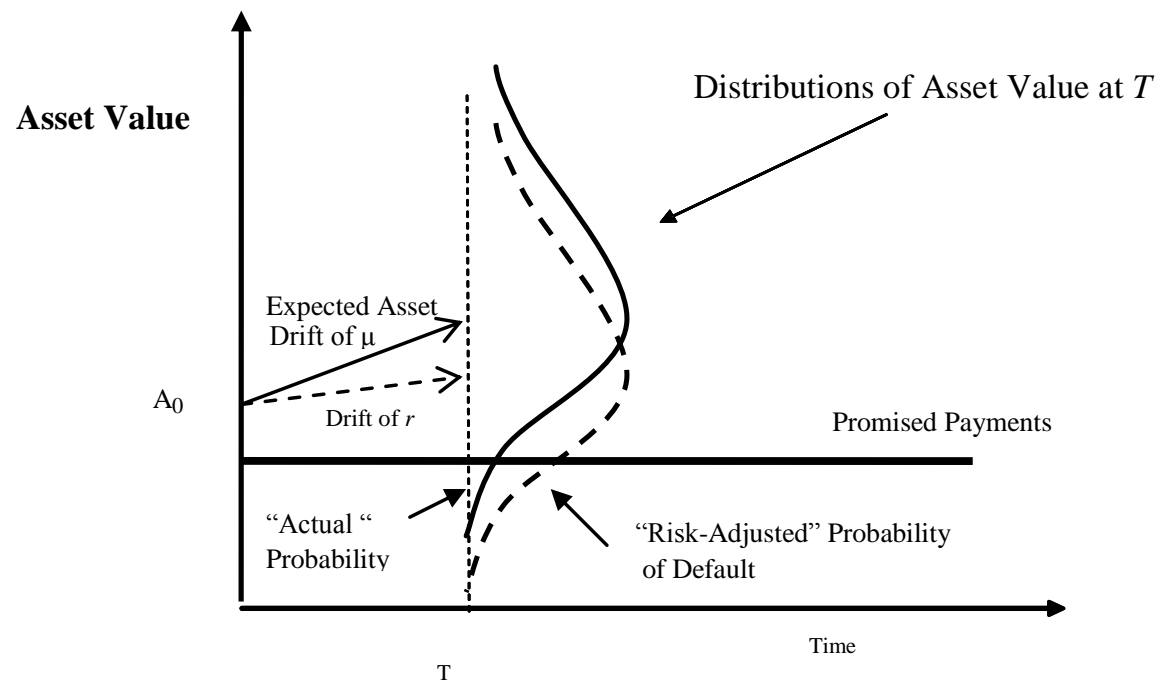

Another important factor that drives spreads of banks (as well as corporates and sovereigns) and affects bank funding cost is change in global risk appetite. The market price of risk is an important parameter in CCA formulas which changes when global risk appetite changes. It is a barometer the level of risk appetite and is used to translate from the real to risk neutral default probability. In the CCA model developed by Moody's KMV, the market price of risk is empirically calculated. It uses the capital asset pricing model together with the CCA model to estimate the market price of risk (MPR) as, $\lambda=\rho_{A, M} S R$, where $\lambda$ is the market price of risk, $\rho_{A, M}$ is the correlation of the bank's asset return with the global market and $S R$ is the global market Sharpe ratio.24 The four stress test scenarios are associated with four scenarios for the market price of risk. An increase in the MPR is associated with a systemic increase in the average volatility of bank assets (including Swedish banks) and associated with an increase in the risk-neutral default probability and the expected losses to bank creditors. Appendix II provides the derivation and the details. The market price of risk reflects investors' risk appetite. It is the "wedge" between the real and risk neutral default probability. These two risk indicators are related by the market price of risk, $\lambda$ :

$$
N\left(-d_{2, \mu}\right)=N\left(-d_{2}-\lambda \sqrt{t}\right)
$$

\footnotetext{
${ }^{23}$ See Merton (1992, pp.334-343; 448-450).

${ }^{24}$ See Crouhy, Galai, and Mark (2000), Bohn (2000), Moody’s KMV (2003).
} 
It can be estimated in several ways. One way is the use of the capital asset pricing model (CAPM) model to estimate the market price or risk is shown in Box 2.

\section{Box 2. Market Price of Risk}

MKMV uses a two moment CAPM to derive the Market Price of Risk (MPR). CAPM states that the excess return of a security is equal to the beta $\beta$ of the security times the market risk $\operatorname{premium}\left(\mu_{M}-r\right)$.

$$
\mu-r=\beta\left(\mu_{M}-r\right)
$$

Beta is equal to the correlation of the asset with the market times the volatility of the asset divided by the volatility of the market.

$$
\beta=\frac{\operatorname{cov}\left(r_{V}, r_{M}\right)}{\operatorname{var}\left(r_{M}\right)}=\rho_{A, M} \frac{\sigma_{A}}{\sigma_{M}} \quad \text { So, } \quad \mu-r=\rho_{A, M} \sigma_{A} \frac{\left(\mu_{M}-r\right)}{\sigma_{M}}=\rho_{A, M} \sigma_{A} S R
$$

Here $S R$ is the Market Sharpe Ratio (this number changes daily but is the same for all firms and financial institutions around the world), and thus $\frac{\mu-r}{\sigma_{A}}=\rho_{A, M} S R$

Using the approach in Box 2 gives:

$$
\begin{gathered}
\lambda=\rho_{A, M} S R \quad \frac{\mu_{A}-r}{\sigma_{A}}=\lambda \\
\mu_{A}=r+\rho_{A, M} S R \sigma_{A}
\end{gathered}
$$

where $\rho_{A, M}$ is the correlation of the asset return with the market and $S R$ is the market Sharpe Ratio. According to MKMV data, $\rho_{A, M}$ is usually around 0.5 to 0.7 (calculated bank by bank in the MKMV CreditEdge model) and the $S R$ around 0.55 to 1.2 during the last few years. ${ }^{25}$ The main driver of the market price of risk in this model is the global Sharpe ratio. The correlation does not change much over time, but the SR changed considerably, see Appendix Figure 12 below.

Changes in risk appetite reflect market risk perceptions and affect credit spreads. The market price of risk, over a one year horizon is $\lambda=\rho_{A, M} S R$ and it provides a way to translate between the actual default probability (EDF) and the risk-neutral default probability. During the financial crisis in 2008 and 2009 the market price of risk rose as GDP in countries around the world fell sharply, including in Israel. In the stress test scenario analysis, for Adverse scenario 2, it is assumed the declining GDP growth corresponds to a severe crisis for Israel and other countries not dissimilar to the 2008 and 2009 crisis. Such a severe crisis would be associated

${ }^{25}$ See MKMV (2003), Crouhy, Galai, and Mark (2000). 
with an increase in the market price of risk. The driver of the MPR is the global Sharpe ratio. Figure 12 shows the historical and projected Sharpe ratio.

Appendix Figure 12. Israel: Historical Market Sharpe Ratio and Projected for Adverse Scenario 2

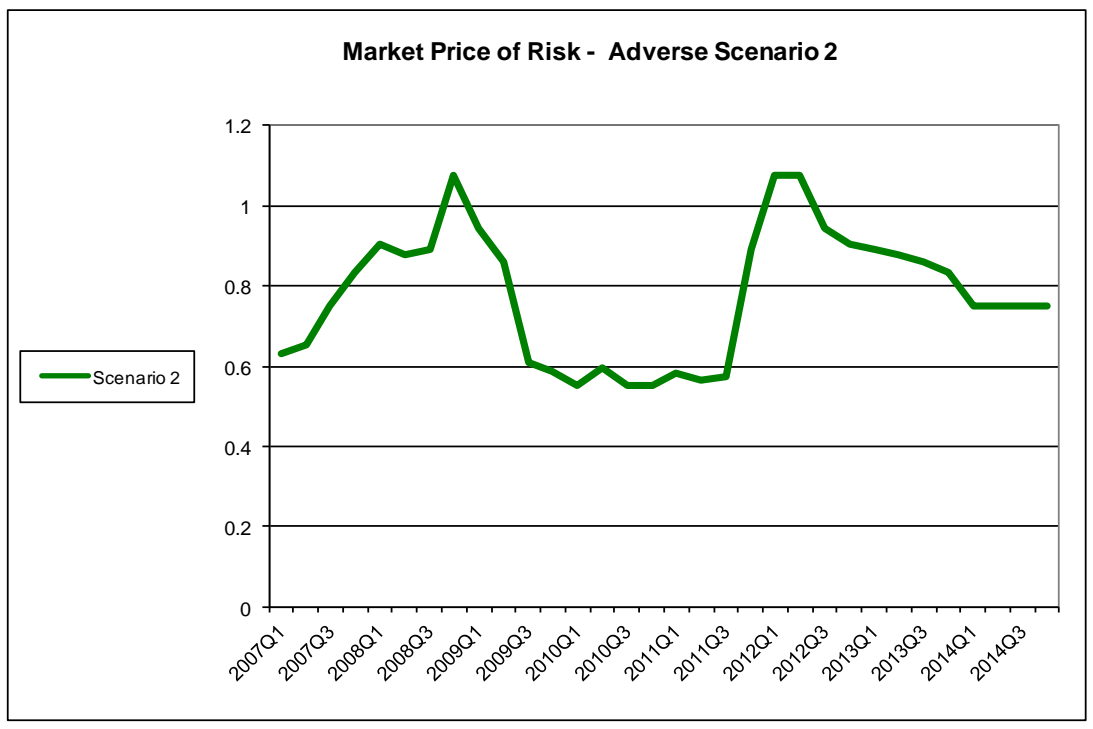

Source: MKMV historical figures, RD and FSAP staff estimates going forward from mid 2011. 


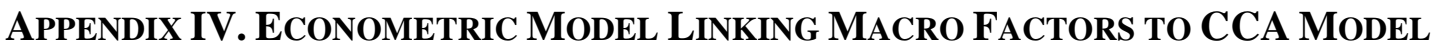

In order to understand the relationship between different banks MKMV data and the macroeconomic environment, the BOI RD developed an econometric model to explain the changes in the bank EDFs and asset return. The model for each institution can be represented by:

$$
y_{i t}=\alpha_{i}+\beta_{i} X_{t}+\varepsilon_{i t}
$$

where $y_{i t}$ is the change in the EDF of institution $i$ or the change in the log of the assets (assets return) and $X_{t}$ is a set of macro variables. As it will be explained shortly, since the sample for each institution is small, we estimated the model in a panel version, so the model that was estimated was:

$y_{i t}=\alpha_{i}+\beta_{i} X_{t}+\gamma_{i}+\delta_{i} I_{i} * \bar{X}_{t}+\varepsilon_{i t}$

where the $\gamma_{i}$ is a fixed effect for each institution and $I_{i} * \bar{X}_{t}$ is an interaction term between the institution and macro variables, in order to catch different affects of the macro variable on each institution's $y_{i t}$. Of course, if $\bar{X}=X$ then we go back to a unique model for each institution which cannot be estimated due to a small sample. Therefore, the decision on which macro variable to include in $\bar{X}$ was made by trying different specifications and using judgment.

The data for estimation of the model consist of the EDFs and asset return for Israel's five largest banks and macro variables. The macro variables are quarterly; we used the quarterly average of the EDF and the assets of each institution, obtaining a sample at the size of 34 observations at the minimum and 59 at the maximum (1997Q1-2011Q3). The macro variables considered were the GDP growth (annual rates, difference from steady state), inflation (annual rates, difference from steady state), depreciation of effective foreign exchange (annual rates, difference from steady state), Bank of Israel short interest rate (annual rates, difference from steady state), TA100 return (annual rates, difference from steady state) and the yield on nonindexed long government bonds (non Indexed, 8-10 years, annual rates) or the gap between this yield and the short interest rate. As mentioned, the sample size range for each institution lies between 34 and 59. These sample sizes - even the maximum - are too small for estimating the model on each institution and some preliminary trials gave no results. Therefore RD set our data an unbalanced panel form and by that got 254 observations for banks (after extracting outliers). The drawback of using panel form analysis is the constant affect each macro variable has on all institutions. RD tried to overcome this drawback by including in some specifications interactions between institutions and macro variables, and by that testing a differential affects of the macro variables. The estimations were made separately for banks (and preliminary estimations for insurance companies). 
Since it is hard to believe an equal variance across institutions, homoscedasticity assumption doesn't hold. Therefore RD estimated the model with GLS, allowing for heteroscedasticity. Allowing autocorrelation was not needed since the two dependent variables are not autocorrelated. Various specifications were tested. In all specifications we first included all the macro variables and then tested for different effects of some macro variables by including fixed effect for each banks and interactions. Variables that were found insignificant in all specifications were omitted. Most of the results make sense in terms of their effect direction. Although further research should be done and more specification to be considered, RD believes that the chosen specification reflect well and logically the relationship between the macro environment and the CCA outputs. Regression results are in Appendix Table 3.

Through the above specifications the RD provided for all institutions until the end of 2014, for all three scenarios and for both assets return and the change in EDF. A 2-standard-errorof-the-prediction confidence interval was calculated for each institution forecast and the main conclusion is that the CI for the insurance sector is wider than the one for the banking sector. Results for the 5 banks EDFs past and projected and fair value spreads past and projected are in Appendix Figure 13. 
Appendix Table 3. Israel: Regression Results for Banks

\begin{tabular}{|c|c|c|}
\hline & Banks - Assets Return & Banks - Change in EDF \\
\hline GDP Growth & $\begin{array}{c}0.0664^{* * *} \\
{[0.0164]}\end{array}$ & $\begin{array}{c}-0.3053^{\star * *} \\
{[0.0772]}\end{array}$ \\
\hline Inflation & $\begin{array}{c}0.0563^{* * *} \\
{[0.0186]}\end{array}$ & $\begin{array}{c}-0.2849^{* * *} \\
{[0.0857]}\end{array}$ \\
\hline Depreciation & & $\begin{array}{c}0.1034^{\star * *} \\
{[0.0266]}\end{array}$ \\
\hline Depreciation (t-1) & $\begin{array}{c}0.0279^{\star * *} \\
{[0.0067]}\end{array}$ & \\
\hline BOI Interest Rate & $\begin{array}{c}0.1955^{\star \star *} \\
{[0.0242]}\end{array}$ & $\begin{array}{c}-0.3813^{* *} \\
{[0.1533]}\end{array}$ \\
\hline Long Interest Rate & & $\begin{array}{l}0.1133^{* *} \\
{[0.0519]}\end{array}$ \\
\hline TA100 Returns & $\begin{array}{c}0.0060^{* * *} \\
{[0.0015]}\end{array}$ & \\
\hline Dummy for inst. 2 & $\begin{array}{c}0.0026 \\
{[0.0022]}\end{array}$ & \\
\hline Dummy for inst. 3 & $\begin{array}{c}0.0085^{\star * *} \\
{[0.0029]}\end{array}$ & \\
\hline Dummy for inst. 4 & $\begin{array}{c}0.0089^{\star * *} \\
{[0.0033]}\end{array}$ & \\
\hline Dummy for inst. 5 & $\begin{array}{c}0.002 \\
{[0.0021]}\end{array}$ & \\
\hline Dummy for inst. 1 X TA100 Returns & & $\begin{array}{c}-0.0652^{* * *} \\
{[0.0178]}\end{array}$ \\
\hline Dummy for inst. 2 X TA100 Returns & & $\begin{array}{c}-0.0449^{* * *} \\
{[0.0074]}\end{array}$ \\
\hline Dummy for inst. 3 X TA100 Returns & & $\begin{array}{c}-0.0255^{\star *} \\
{[0.0104]}\end{array}$ \\
\hline Dummy for inst. 4 X TA100 Returns & & $\begin{array}{c}-0.1446^{* * *} \\
{[0.0368]}\end{array}$ \\
\hline Dummy for inst. 5 X TA100 Returns & & $\begin{array}{c}-0.0560^{\star * *} \\
{[0.0203]}\end{array}$ \\
\hline Observations & 254 & 207 \\
\hline Constant & $\begin{array}{c}0.0074^{* * *} \\
{[0.0015]}\end{array}$ & \\
\hline Number of id & 5 & 5 \\
\hline
\end{tabular}

Standard errors are in brackets. $* * *-1$ percent significance, $* *-5$ percent significance, $*-10$ percent significance. The smaller samples in rows 3 and 4 are a result of using the long interest rate, which its data is available only since mid 2001. 


\section{Appendix Figure 13 Israel: CCA Stress Test Results}

\section{CCA Stress Test Results - 1 year EDF (percent) and Fair Value Credit Spreads (bps)}

Weighted Average EDF 5 banks past and Base scenario

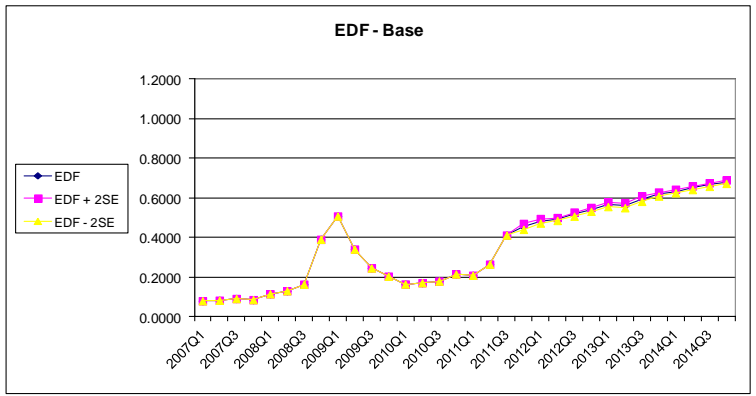

Weighted Average EDF 5 banks past and Adv 1 scenario

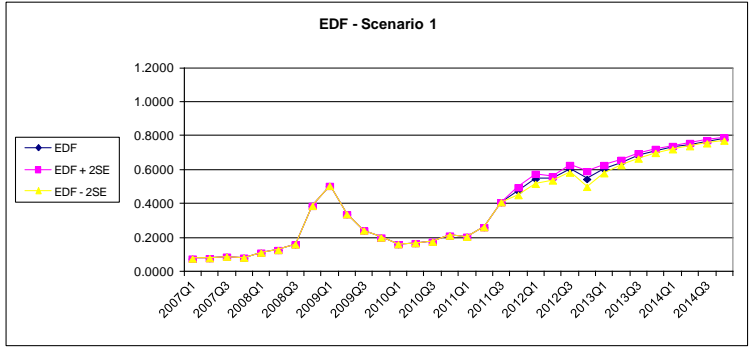

Weighted Average EDF 5 banks past and Adv 2 scenario

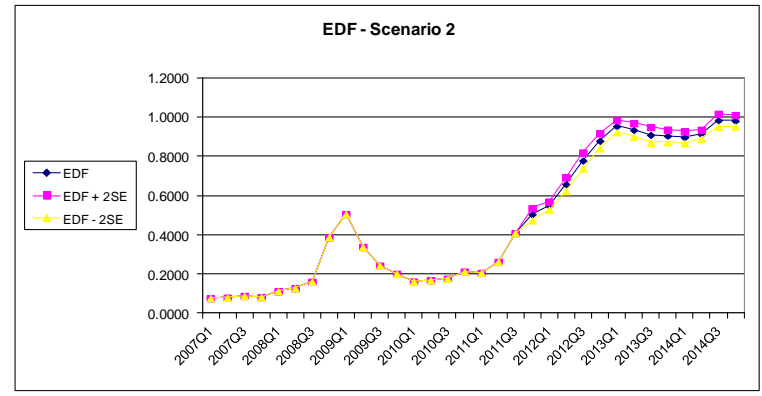

Weighted Average 5 yr FV spread (bps) banks past and Base scenario

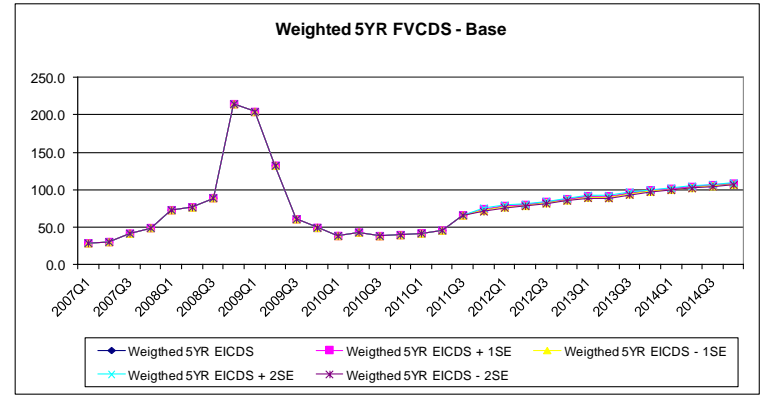

Weighted Average 5 yr FV spread (bps) banks past and Adv 1 scenario

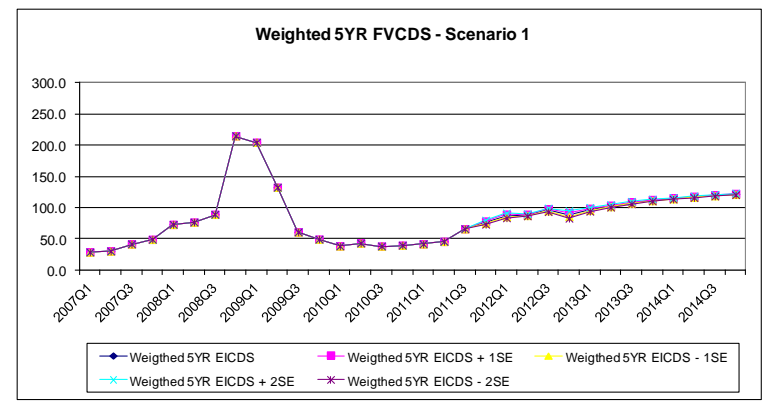

Weighted Average 5 yr FV spread (bps) banks past and Adv 2 scenario

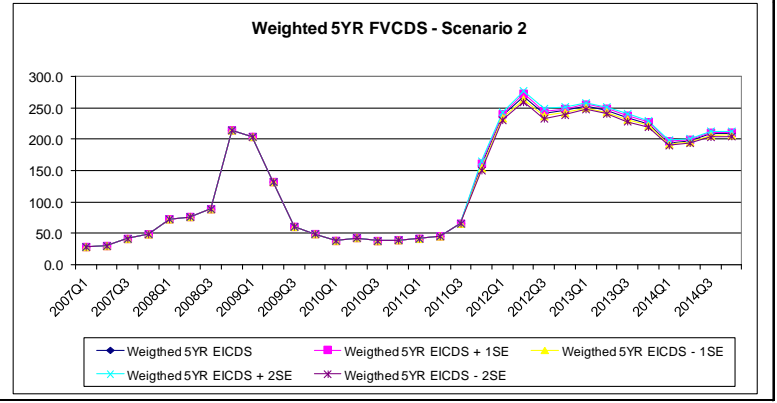


Appendix V. Insurance Test Matrix for Long Term Savings Providers

\begin{tabular}{|c|c|c|}
\hline Domain & Element & Assumptions for Top Down Stress Tests \\
\hline Institutions & $\begin{array}{l}\text { Life insurers, } \\
\text { pension funds and } \\
\text { provident funds }\end{array}$ & $\begin{array}{l}\text { - The whole market of long term savings is included, } \\
\text { differentiated by type of provider. }\end{array}$ \\
\hline Market share & $\begin{array}{l}\text { Assets, reserves, } \\
\text { premia }\end{array}$ & $\begin{array}{l}\text { - } 100 \text { percent of the market } \\
\text { - NIS } 140 \text { billion insurance providers } \\
\text { - NIS } 300 \text { billion, provident funds } \\
\text { - NIS } 95 \text { billion, new pension funds }\end{array}$ \\
\hline Data & Source & - Regulatory data as of June 2011 \\
\hline Methodology & supervisory models & - Immediate shock on the value of the portfolio \\
\hline $\begin{array}{l}\text { Stress test } \\
\text { horizon }\end{array}$ & Duration & - Immediate shock on the value of the portfolio \\
\hline Shocks & $\begin{array}{l}\text { Scenario analysis } \\
\text { Single factor shocks }\end{array}$ & $\begin{array}{l}\text { - Historic based scenario: } 4^{\text {th }} \text { Quarter } 2008 \\
\text { - } \quad \text { Foreign investments }-15 \text { percent } \\
\text { - } \text { Loans }-4.4 \text { percent } \\
\text { - } \text { Gorporate bonds }-9.4 \text { percent } \\
\text { - } \text { Equity }-29.8 \text { percent } \\
\text { - Simulated local shock scenario: } \\
\text { - FX depreciation }-20 \text { percent } \\
\text { - } \text { Corporate spread } 200 \text { bp } \\
\text { - Risk free interest }+20 \text { percent } \\
\text { - Equity }-30 \text { percent }\end{array}$ \\
\hline Risk factors & $\begin{array}{l}\text { (e.g., equity prices, } \\
\text { yield curve, } \\
\text { production, lapses, } \\
\text { etc.). }\end{array}$ & - (See above) \\
\hline $\begin{array}{l}\text { Behavioral } \\
\text { adjustments }\end{array}$ & $\begin{array}{l}\text { Managerial and } \\
\text { policyholders' } \\
\text { reactions (none for } \\
\text { one-year horizon) }\end{array}$ & - None \\
\hline \multirow[t]{2}{*}{$\begin{array}{l}\text { Regulatory } \\
\text { standards }\end{array}$} & $\begin{array}{l}\text { Definition of } \\
\text { solvency (risk- } \\
\text { sensitive regime is } \\
\text { necessary) }\end{array}$ & $\begin{array}{l}\text { - No capital impact since focus on depreciation of portfolio } \\
\text { value }\end{array}$ \\
\hline & $\begin{array}{l}\text { Accounting } \\
\text { requirements (mark- } \\
\text { to-market valuation } \\
\text { is preferable) }\end{array}$ & - Mark to market valuation \\
\hline Results & Asset losses & $\begin{array}{l}\text { - Historic based scenario: } 4^{\text {th }} \text { Quarter } 2008 \\
\text { - } 9.45 \text { percent loss in LTS provided by insurers } \\
\text { - } 7.47 \text { percent loss in LTS provided by provident funds } \\
\text { - } 5.58 \text { percent loss in LTS provided by pension funds } \\
\text { - Weighted average } 7.70 \text { percent loss } \\
\text { - } \text { imulated local shock scenario: } \\
\text { - } 3.28 \text { percent loss in LTS provided by insurers } \\
\text { - } 5.43 \text { percent loss in LTS provided by provident funds } \\
\text { - } 2.55 \text { percent loss in LTS provided by pension funds } \\
\end{array}$ \\
\hline
\end{tabular}




\section{REFERENCES}

Bank of Israel - Various documents from BSD and RD related to stress testing models and results.

Black F. and M. Scholes, 1973, "The Pricing of Options and Corporate Liabilities," J. Polit. Econ., Vol. 81, No. 3, pp. 637-54.

Bohn, J. (2000) An Empirical Assessment of a Simple Contingent Claims Model for the Valuation of Risky Debt, Journal of Risk Finance, 1, 55-77.

Crouhy, M., D. Galai, and R. Mark. (2000) Risk Management, McGraw Hill, New York.

Gray, D. F., 2009, "Modeling Financial Crises and Sovereign Risk," Annual Review of Financial Economics (edited by Robert Merton and Andrew Lo)," Annual Reviews, Palo Alto California, USA.

Gray, D. F., and A. A. Jobst, 2010, "New Directions in Financial Sector and Sovereign Risk Management, Journal of Investment Management, Vol. 8, No.1, pp. 23-38.

Gray, D. F., and A. A. Jobst, forthcoming, "Systemic Contingent Claims Analysis (Systemic CCA)_Estimating Potential Losses and Implicit Government Guarantees to Banks," IMF Working Paper (Washington: International Monetary Fund), forthcoming.

Gray D. F. and S. Malone. 2008. Macrofinancial Risk Analysis. New York: Wiley.

Gray, D. F., Merton R. C. and Z. Bodie, 2008, “A New Framework for Measuring and Managing Macrofinancial Risk and Financial Stability," Harvard Business School Working Paper No. 09015 .

Haldane, Andrew G., 2011, "Capital Discipline," paper based on a speech given at the American Economic Association, Denver, United States, January.

International Monetary Fund, 2008a, "Global Financial Stability Report: Containing Systemic Risks and Restoring Financial Soundness", World Economic and Financial Surveys (International Monetary Fund: Washington, D.C.)

, 2010a, Sweden Art IV, Selected Issues Paper, (International Monetary Fund: Washington, D.C.)

, 2010b, United States Financial Sector Assessment Program Technical Note on Stress Testing, July, (International Monetary Fund: Washington, D.C.).

, 2011 (draft, forthcoming), Sweden Financial Sector Assessment Program Update, Technical Note on Stress Testing of the Banking Sector, July, (International Monetary Fund: Washington, D.C.). 
Merton, R. C., 1973, “Theory of Rational Option Pricing,” Bell J. Econ. Manag. Sci., 4 (Spring), pp. 141-83.

Merton, R. C., 1974, “On the Pricing of Corporate Debt: The Risk Structure of Interest rates," J. Finance 29 (May), pp. 449-70.

Merton, R. C., 1977, “An Analytic Derivation of the Cost of Loan Guarantees and Deposit Insurance: An Application of Modern Option Pricing Theory," Journal of Banking and Finance, Vol. 1, pp. 3-11.

Moody’s KMV (2003) Modeling Default Risk, KMV Corp.

BOI background documents on satellite models, credit risk, stress testing, and econometric results for various stress test models. 